\title{
NORMATIVE AND LEGAL PLURALISM: A GLOBAL PERSPECTIVE
}

\author{
WILLIAM TWINING* \\ THE SEVENTH ANNUAL HERBERT L. BERNSTEIN MEMORIAL \\ LECTURE IN INTERNATIONAL AND COMPARATIVE LAW
}

AS HELD AT DUKE UNIVERSITY SCHOOL OF LAW APRIL 7, 2009

\begin{abstract}
This lecture sets out to demystify the topic of legal pluralism by examining the relationship between legal pluralism, normative pluralism, and general normative theory from a global perspective. The central theme is that treating legal pluralism as a species of normative pluralism decenters the state, links legal pluralism to a rich body of literature, and helps to show that some of the central puzzlements surrounding the topic can usefully be viewed as much broader issues in the general theory of norms and legal theory. A second theme is that so-called "global legal pluralism" is in several respects qualitatively different from the older anthropological and socio-legal accounts of legal pluralism and is largely based on a different set of concerns.
\end{abstract}

* Emeritus Quain Professor of Jurisprudence, University College London; Visiting Professor, University of Miami School of Law. This is a revision and expansion of the Bernstein Lecture, delivered at Duke University School of Law on April 7, 2009. It is one of a series of works exploring the implications of adopting a global perspective for academic law and for jurisprudence as its theoretical, or more abstract, part. Others in the series are WILLIAM TWINING, GENERAL Jurisprudence: Understanding LAW From A Global Perspective (2009), William Twining, Social Science and Diffusion of Law, 32 J. L. SoC'Y 203-40 (2005), William Twining, Law, Justice and Rights: Some Implications of a Global Perspective, in ENVIRONMENTAL LAW AND JUSTICE IN CONTEXT 76 (Jonas Ebbeson \& Phoebe Okowa eds., 2008); Globalisation and Comparative Law, in COMPARATIVE LAw: A HANDBOOK 69 (Esin Örücű \& David Nelken eds., 2007), William Twining, Implications of 'Globalisation' for Law as a Discipline, in THEORISING THE GLOBAL LEGAL ORDER 39 (Andrew Halpin \& Volker Roeben eds., 2009), WiLliam Twining, GLOBALISATION AND LEGAL THEORY (Northwestern University Press 2001) (2000), Institutions of Law From a Global Perspective: Standpoint, Pluralism and Non-State Law, in LAW AS InSTITUTIONAL Normative Order (Macksymillian Del Mar \& Zenon Bankowski eds., 2010). I am grateful to Terry Anderson, Shaun Larcom, Brian Tamanaha and the editors for helpful comments and suggestions. I am especially indebted to Ralf Michaels both for his careful critique of an earlier draft and for the insights in his recent writings on legal pluralism. 
After a brief Introduction, Part I considers normative pluralism. It explores the ambiguity of "pluralism" and some themes in general normative theory. Part II introduces the heritage of literature on legal pluralism. It presents an ideal type of social fact legal pluralism to which much, but by no means all, of the mainstream literature approximates. Some brief case studies illustrate some distinctions that are increasingly under attack. Part II suggests that social fact pluralism has achieved much in raising awareness of non-state normative orders, but provides little guidance on issues of state policy and institutional design. Part III considers the implications of adopting a global perspective in this context. It questions how far social fact legal pluralism is helpful in addressing a wide range of concerns raised by "globalization" and argues that the radically ambiguous idea of "global legal pluralism" is being applied to such a variety of phenomena and concerns as to be virtually meaningless.

\section{INTRODUCTION}

It is an honor and a pleasure to give this lecture in memory of so wellloved and respected a comparative lawyer. I feel a bit of a fraud, for I am not a comparatist by specialization, but rather by situation, as all academic lawyers are today. I have chosen my topic because legal pluralism has in the last ten years or so become a central topic in the study of law generally, including jurisprudence, comparative law, and public international law. This is largely, but not entirely, in response to so-called "globalization." Yet this expansion of interest threatens to sow the seeds of confusion.

The excitement and confusion about legal pluralism is captured by a leading scholar of the subject, Gad Barzilai:

Legal pluralism has been one of the most salient and influential academic trends in law and society scholarship since the 1970s. It primarily articulates detachment from legal centralism revolving around state law, criticism of the exclusiveness of state law, decentralization of court-centered judicial studies, exploration of nonstate legal orders, unveiling of informal socio-legal practices, and an understanding of law as a multi-centered field that deals with the convergence of norms, localities, states, global sites, and practices. Scholarship of legal pluralism has underscored the ways in which various identities and traditions have decentralized state law and offered non-state legal orders. ${ }^{1}$

1. Gad Barzilai, Beyond Relativism: Where is Political Power in Legal Pluralism?, 9 THEORETICAL INQUIRIES IN L. 395, 396 (2008). 
A considerable amount of controversy has surrounded the topic: some jurists reject the very term "legal pluralism" as an oxymoron, referring "to legal pluralists" as if they are a strange sect ${ }^{2}$ some see it as a site for rerunning long-standing debates about the concept of law and positivism versus non-positivism; many different answers are given to the question: "plurality of what?"; some associate the idea with post-modernism; and some even talk of a new "global legal pluralism."

My standpoint is that of an English jurist who is concerned about the somewhat disorderly proliferation of literature and perspectives on legal pluralism in the wake of the growing interest in so-called "globalization." My aim is to suggest a way into this confusing literature and to demystify at least some aspects of the issues.

\section{NORMATIVE PLURALISM}

If one treats legal pluralism as a species of normative pluralism, it is helpful to start with the wider category. Think of all the rules and norms you have encountered in the last few hours. Many of you, having followed various morning routines, such as brushing your teeth or swallowing pills, will have obeyed or flouted North Carolina traffic laws, observed local driving etiquette, grumbled about the university's parking regulations, greeted colleagues and students, respected the law school's ban on smoking, but brought coffee into the library despite the notices. You will have followed intricate sets of commands in checking your voice mail and starting your computer. You may have been worried by a circular from the central administration about plagiarism. In drafting a memo or e-mail message you will have accepted or surrendered to American usages of grammar and spelling, and you may even have consulted the Harvard Bluebook or a dictionary.

You may have violated some norms of which you are unaware, and noticed but disregarded some that you do not feel apply to you, such as fashions in tattoos or new conventions of spelling of text messages. Glancing through the newspaper you may have encountered the U.S. Constitution, the WTO and IMF, North Carolina state law, European Union directives, Israeli law, Islamic banking practices, the rules of tennis, funerals in Baghdad, or Afghanistan, the Torture Convention and numerous examples of treaties, customs, conventions, folkways, mores, and "soft law." And just now we have all witnessed the complex code of rituals that are conventional at a public lecture.

2. See discussion infra accompanying note 7 . 
When I set my students to compile a list of all the rule systems they have encountered in a 48 hour period, only the lazy ones come up with less than a hundred items. ${ }^{3}$ We all encounter normative pluralism every day of our lives. ${ }^{4}$ For the most part we cope with it without thinking. ${ }^{5}$ We treat it as a social fact. Occasionally, it throws up acute dilemmas or obstacles, but on the whole we skillfully navigate our way through and round dozens of kinds of rules as a routine form of multi-tasking. Only if someone asks: "how do you manage?" are you in danger of paralysis, like the centipede who was asked how she coordinated her legs. That is rather like Italo Calvino's Mr. Palomar, who, wanting to master the universe, set out by trying to describe a single wave, and gave up in depression. ${ }^{6}$ We can live with normative pluralism so long as we don't ask too many questions about it.

So we all encounter normative pluralism every day. It is hard to deny it as a social fact. Yet when lawyers hear about legal pluralism many are puzzled, even resistant to the idea. They even talk of "legal pluralists" as a deviant sect, treating "legal pluralism" as a perspective rather than as a social fact. ${ }^{7}$ It is fairly obvious that the main puzzles are to do with the what counts as "legal" (rather than what is plural) and that nearly all writing about legal pluralism adopts or presupposes a broad conception of law that extends beyond the "Westphalian Duo" of the municipal or domestic law of sovereign states and public international law conceived as dealing with relations between such states. So discussions about legal pluralism are, perhaps inevitably, drawn into long-standing concerns about problems of conceptualizing law. Before addressing these head on, let us

3. See William Twining, Globalisation and Legal Theory 83, 259-60 (Northwestern University Press 2001) (2000) [hereinafter TwINING, GLT].

4. In this context "normative pluralism" broadly refers to be the coexistence in the same timespace context of multiple systems of norms or rules or of institutionalized normative orders - concepts that need closer examination; see discussion infra accompanying note 9.

5. Cf. Robert Frost, The Silken Tent, in The Poems of Robert Frost 385 (1946) (“. . . only by one's going slightly taut in the capriciousness of summer air, is of the slightest bondage made aware").

6. Italo Calvino, Mr. Palomar (Guilio Einaudi ed., William Weaver trans., Harcourt Brace Jovanovich, Inc. 1985) (1983).

7. See Franz von Benda-Beckmann, Who's Afraid of Legal Pluralism?, 47 J. L. PLURALISM AND UNOFFICIAL L. 37, 72-74 (2002) (criticizing Roberts and Tamanaha, among others, for being "instrumental in creating "the bogeyman of legal pluralists"); Simon Roberts, Against Legal Pluralism: Some Reflections on the Contemporary Enlargement of the Legal Domain, 42 J. L. PLuRALISM AND UnOFFICIAL L. 95 (1998); Brian Tamanaha, The Folly of the 'Social Scientific' Concept of Legal Pluralism, 20 J. L. SoC'Y 192, 192 (1993) [hereinafter Tamanaha, Folly of Social Scientific]. Of course, the term "legal pluralist" is also used to refer to scholars who have studied the phenomenon rather than to an eccentric belief in the phenomenon. 
first take a preliminary look at the seemingly less problematic idea of "pluralism."

\section{A. "Pluralism"}

"Pluralism" is used in many contexts and tends to be bandied about rather loosely. Let us dispose briskly of some uses that are not directly relevant here. "Plural," usually contrasted with singular, means more than one, applied to persons or objects. It assumes that those persons or objects are discrete or individuated. The primary meaning of "pluralist" is the state of being plural. There are certain special applications that we can set on one side: for example "a pluralist" can refer to "[O]ne who holds two or more offices, especially ecclesiastical benefices, at the same time." 8 "Pluralistic" can mean diverse or varied. In ethics, typically contrasted with monism, pluralism is a normative concept, referring to "a theory or system that recognizes more than one ultimate substance or principle." 9 On the other hand, belief pluralism refers to a situation in which different cosmologies or belief systems coexist, a social fact of considerable significance in the current context of "globalization," not least in relation to claims about the universality of human rights or natural law principles. ${ }^{10} \mathrm{~A}$ related usage equates pluralism with "multi-culturalism." For example, Webster gives as a second meaning of "pluralist": "the nature of a society within which diverse ethnic, social, and cultural interests exist and develop together." However, in some contexts the term "multi-culturalism," contrasted with assimilation, has been extended from referring to a social fact about a society to a normative concept referring to strategies and policies in such a society directed at respecting and maintaining cultural diversity in various ways. More directly related to legal pluralism is the special meaning of "pluralism" in political science, rendered by the Oxford English Dictionary ("OED”) as "A theory which opposes monolithic state

8. The Living Webster Encyclopedic Dictionary of The English Language (1981). The OXFORD ENGLISH DictionARY (John Simpson \& Edmund Weiner eds., 1989) suggests that this was the original usage and that other meanings are extensions.

9. See Webster EnCYlOPEDIC Dictionary, supra note 8; The OXFORD ENGLiSh Dictionary recognizes a special meaning of "pluralism" in ontology as "the theory that the knowable world is made up of a plurality of interacting things." Susan Haack, echoing William James, writes of "The pluralistic universe of the law," emphasizing "the richness and variability of the legal systems of the world (interpreted broadly), past and present, their complicated interrelations, and their roots in commonalities of human nature and society." She links this to a classical pragmatist ontology. Susan Haack, The Pluralistic Universe of Law: Towards a Neo-classical Legal Pragmatism, 21 RATIO JURIS 453, 456-57 (2008) (citing William A. JAMES, A PLURALISTIC UNIVERSE (1909)).

10. See William Twining, General Jurisprudence: Understanding LaW From a Global PERSPECTIVE 131 (2009).

11. WEBSTER ENCYCLOPEDIC DiCTIONARY, supra note 8. 
power and advocates instead increased devolution and autonomy for the main organizations that represent man's involvement in society." 12

It is not my intention to provide an extended lexicographical or semantic analysis of these various usages and applications, which are only indirectly relevant to my thesis. But it is worth noting two points. First, to talk of objects in the plural presupposes that they can be individuated. Second, there is a general tendency in some contexts to move from an empirical to a normative usage, as is illustrated by the two primary usages of "multi-culturalism."

In the present context in relation to normative pluralism it is worth asking: plurality of what exactly? Among my examples are some that are conventionally regarded as legal, others that are generally regarded as "non-legal," and some (such as "soft law" and religious law) that are contested. Setting aside concerns about "the legal," one can roughly differentiate three categories that are explicitly mentioned or implied: institutionalized normative orders (e.g., the WTO, the regime of internal governance of a law school or a university or large organization); a system, or code or discrete set of norms (the U.S. Constitution, the rules of football); looser aggregations of norms (public lecture rituals, American spelling); and a few single norms which do not clearly belong to any one system or agglomeration (is the smoking ban part of the rules governing the library, the law school, the university or something more general?). ${ }^{13}$ There is plenty of scope for disagreement about these general categories and about how particular examples might be categorized. The important point here is that "normative pluralism" can be applied to a variety of types of individuated units. Similarly, as we shall see, "legal pluralism" is variously applied to institutionalized legal orders, systems, codes or other bodies of rules, sources of law, and to single rules or principles (e.g., the rule in Rylands $v$ Fletcher, the principle that no person should profit from her own wrong). The general point is that in any discussion of normative or legal pluralism, it is important to have a reasonably clear answer to the question: plurality of what? In this lecture, I shall focus mainly on institutionalized normative orders. ${ }^{14}$

12. On contested meanings of "pluralism" in political science, see discussion infra accompanying note 39 .

13. Are the rules governing watching television your home "rules of television watching," or a mixture of different types, such as norms of turn-taking and courtesy, an aspect of rules governing bedtime and homework ("family discipline?") or part of some broader set of "home rules" or "house rules?" See William Twining \& DAVID Miers, How to Do Things With Rules 10-34 (5th ed. 2010).

14. See TwINING, supra note 10, at 116-21, 122-53 (discussing relationship between institutions, social practices, and systems, orders, codes, or sets of rules). 


\section{B. General Theory of Norms}

Moving our focus from legal to normative pluralism provides a direct link to the general theory of norms. Some puzzlements relating to normative pluralism belong to general normative theory: for example, under what conditions is it true to say that a rule or norm exists? In a given context, how can norms best be classified? What counts as one rule or one norm (the problem of individuation)? What is meant by a system or order or code of norms? And many questions about "normativity": for example, what is the relationship between norms and obligation, authority, acceptance, legitimacy, and legality? ${ }^{15}$ These are not puzzlements about the concept of pluralism as such, but they often arise in discussions about legal pluralism and sometimes in the less-discussed context of theorizing normative pluralism. Our heritage of theorizing about such issues includes important contributions from moral philosophy, logic, speech act theory, sociology, game theory, economics, decision theory, and jurisprudence, among others. Despite brave efforts by David Lewis, Joseph Raz, Frederick Schauer, and many others, ${ }^{16}$ we are a long way from having a settled framework of basic concepts let alone a fully integrated overarching general theory of norms. There is no agreed vocabulary, no settled taxonomy of types of rules or norms, and an uneven body of theorizing about a bewildering range of issues. Our centipede trying to make sense of the wide range of rules, norms, and practices that one encounters in daily life - what I have crudely designated as normative pluralism - will find herself stumbling into a philosophical morass. Here I intend to skirt this morass, but get sufficiently close to illustrate the general point: many puzzles about normative pluralism are about concepts and issues that belong to the general theory of norms rather than about the idea of pluralism. Let us consider briefly three topics in the general theory of

15. Cf. Ralf Michaels \& Nils Jansen, Private Law Beyond the State? Europeanization, Globalization, Privatization, 54 AM. JO. COMP. L. 843, 874-82 (2006) (Michaels usefully surveys implications of globalization in respect to issues of validity, method, legitimacy, and autonomy in relation to private law). On recent discussions in legal philosophy of the normativity of law, see discussion infra accompanying notes 31-35.

16. See, e.g., Jurgen Habermas, Between FACts AND Norms: Contributions to A Discourse THEORY OF LAW AND DEMOCRACY (William Rehg trans., 1996); DAVID K. LEWIS, CONVEntion: A PHILOSOPHICAL STUDY (Blackwell Publishers Ltd. 2002) (1969); HANS KelsEN, GENERAL THEORY OF NORMS (Michael Hartney trans., 1991); JOSEPH RAZ, PrACTICAL REASON AND Norms (Princeton University Press 1990) (1975); Frederick SCHAUER, Playing By The RULEs: A Philosophical Examination of Rule-Based Decision-Making in LaW and Life (1991); Edna Ullman-Margalit, The Emergence of Norms (1977). See also John Griffiths, The Social Working of Legal Rules, 48 J. L. Pluralism AND UnOfFicial L. 1, 1 (2003); Twining \& Miers, supra note 13, at 123-56. 
norms: (1) norms, rules, and related concepts; (2) classification of norms; and (3) problems of individuation.

\section{Norms, rules, and related concepts}

There is no uniformity of usage across disciplines of "norm" or "rule" in normative theory. For the sake of brevity I shall resort to stipulation. In the present context I shall use "rule" as a broad generic term that covers empirical generalizations ("as a rule he..."), practices and customs and many logical types of general prescription. ${ }^{17}$ The term norm in this context is confined to those rules that are "normative" in that they can be expressed in terms of must or ought (mandatory), may (permissive), or can (powerconferring). ${ }^{18}$ To put it simply, we are here concerned with general prescriptions that guide behavior and provide reasons for action. There are further problems surrounding concepts that seemingly combine descriptive and normative elements such as custom, social practice, and convention. ${ }^{19}$

\section{Classification of rules and norms}

There is no settled vocabulary in relation to rules and norms; nor is there any settled way of classifying them. Norms can be classified for different purposes by their logical types, their sources, the kinds of activity they govern, who are subject to them, who follow them, their degree of articulation and formality and so on. ${ }^{20}$ My list of rules that we encounter daily is extremely varied. Some, such as parking rules, chess rules, and spelling conventions are generally independent of each other in their force and are not usually connected with each other in our minds. Some, such as rules regulating driving on campus or banning smoking, have complex relations with other types of rules.

It is common to treat legal institutions as species of the genus social institutions and legal norms as species of social norms. Accepting this for the sake of argument, it may be useful in the context of considering normative pluralism to distinguish between social norms and other norms.

17. See generally TWINING \& MIERS, supra note 13 .

18. See RAZ, supra note 16, at 117. I follow Joseph Raz in treating rules as a broad generic category which covers a variety of logical types. The word "norm" is a technical term that covers those species of rules that involve some kind of prescription. The term "rule" is sometimes used to refer to actual regularities of behavior, and to prudential rules and rules of thumb, all of which fall outside the category of norms. At the borderline are rules that do not directly guide behavior, but have indirect normative effects such as rules defining the number of players in chess or bridge. So the rule that chess is a game involving two players is not a norm, but the rule that bishops may move diagonally, but only diagonally, is a norm.

19. See TwINING, supra note 10 , at 99-103 (discussing social practices).

20. RAZ, supra note 16 , at 107. 
Then, in considering legal pluralism, we can focus our attention on social norms. Such a distinction would justify our intuition that some of my examples - such as norms about brushing one's teeth, or grammar, or spelling-are not serious candidates for the label "legal." Within the category of social norms there will still be a need to differentiate "the legal" and "the non-legal," but at least we can discard all other norms as falling outside this topic.

However, the distinction between social norms and other norms can be problematic. First, there is a threshold ambiguity. "Social norms" may refer to the norms of a given group, community, or society or they may refer more broadly to any norm that guides or governs social relations. Most examples of normative pluralism relevant here relate to social norms associated with a particular group or community. But, second, although less debated in the literature, the distinction between norms that govern social relations and other norms is problematic. For example, are not conventions of spelling and syntax and rules underlying the deep structure of language "social" in that they govern communication between human beings? If so, should we not treat all linguistic norms as a sub-category of social norms? Are rules of games all social? Many of the rules of soccer or baseball govern relations between participants (including officials), but are the rules prescribing scoring or the size of tennis courts "social"? In what sense, if at all, are the rules that constitute chess or solitaire, "social"? One does not need to go very far down this route to realize that conceptualizing the social may be almost as problematic as conceptualizing "law."

There is no agreed taxonomy of types of social norms. Lawyers regularly distinguish between principles, precepts, general commands, regulations, instructions, ${ }^{21}$ conventions, guidelines, standards, maxims, rules of thumb, and so on, without working with a standard taxonomy. Herbert Hart usefully distinguished between rules (norms in our sense) and commands, habits, and predictions and more controversially, between primary and secondary rules. ${ }^{22}$ For present purposes, I shall take such distinctions as given - although admittedly some are not unproblematic. Similar considerations apply to the relationship between social and moral

21. See Jeremy Bentham, An Introductory View of the Rationale of Evidence; For the Use of NonLawyers As Well As Lawyers, in 6 THE WORKS OF JEREMY BENTHAM 151-52 (Sir John Bowring ed., 1843) (Bentham usefully distinguished between rules addressed to the will, and instructions (cautionary instructions, "guiding principles" "admonitory maxims") addressed to the understanding); see also William Twining, TheOries OF Evidence: BenthAM AND Wigmore 43-44, 66-75 (1985) (noting that Bentham's distincition was crucial in respect of evidence in that his "anti-nomian thesis" was directed only to peremptory rules).

22. H.L.A. HART, THE CONCEPT OF LAW 18-20, 50-89 (1961). 
norms. The main point in the present context is that insofar as there are conceptual and taxonomic problems about rules and norms, these puzzles are not specifically about pluralism, but belong to normative and legal theory generally.

\section{Individuation}

If "plural" means more than one, it suggests relatively discrete countable units. But what counts as one normative order or one norm? And how discrete does it have to be? This brings us to the problem of individuation.

Problems of individuation are among the most profound questions in philosophy. ${ }^{23}$ In jurisprudence questions about individuation of laws puzzled Jeremy Bentham who asked: what constitutes one law? What constitutes a complete law ${ }^{24}$ So these are not puzzles confined to legal pluralism. In the context of theorizing normative and legal pluralism there are conceptual problems concerning the individuation of norms, laws, normative order, legal orders or legal systems, and cultures to say nothing of civilizations and traditions. ${ }^{25}$ It is quite widely recognized by jurists that it can be misleading to talk of single norms or rules or laws as discrete units that can be counted, compared, classified, or thought of in terms of interaction or influence or other forms of interlegality. One familiar move is to postulate that all norms, laws, and legal rules belong to some larger unit such as a system, order, or code. ${ }^{26}$ To ask how many rules there are in the Uniform Commercial Code ("UCC") seems like a silly question. It is rather like asking: how many strands are there in a spider's web or in this elaborately woven blanket? ${ }^{27}$

23. W.V. Quine, Speaking of Objects, in ONTOLOGICAL RELATIVITY AND OTHER EsSAYs passim (1969) (arguing against a relaxed attitude to individualization by the precept "no entity without identity").

24. Jeremy Bentham, Of Laws in General, in The Collected Works of Jeremy Bentham (H.L.A. Hart ed., 1970); Joseph RAZ, THE CONCEPT OF A LEGAL SYSTEM: AN INTRODUCTION to THE THEORY OF LEGAL SYSTEM 70-92 (2d ed. 1980).

25. See Twining, supra note 10, at 78-87 (discussing Fernand Braudel on the concept of "civilization" and H. Patrick Glenn's concept of "tradition").

26. See RAZ, supra note 24 (proposing that all laws necessarily belong to a legal system); TONY HoNORÉ, MAKING Law BIND: ESSAYs LEGAL AND PHILOSOPHICAL 38-45 (1987). See generally HART, supra note 22 , at $77-96$.

27. This response seems quite sensible, but it does not fully resolve the difficulties. In some contexts it is convenient to treat the legal system of England and Wales, Cheyenne Law, or the Uniform Commercial Code as discrete entities without specifying precisely what they encompass. But the question may arise: does the Uniform Commercial Code include the comments, amendments, authoritative interpretations of its provisions, and underlying assumptions about the nature of codes in general or this particular code? The answer to such questions largely depends on context. 
But this moves the problem of individuation to a more general level. Concepts such as order, system, and code are useful, perhaps indispensable, constructs. But there are also familiar dangers in treating the referents of such nouns as firm, stable, bounded, discrete entities. It is almost a cliché that they are often more like clouds or waves than rocks or billiard balls. ${ }^{28}$ Often they are not as internally homogeneous or monolithic as the discourse suggests. $^{29}$

In the context of discussions of normative and legal pluralism, order, system, code, and culture all present conceptual problems. If one asks: under what conditions is it true to say that a normative order exists? One is tempted to give a rather vague answer. One example might be in the form of a definition per genus et differentiam: for example, a normative order is a set of norms or social practices oriented towards ordering relations between members of a community or group where this set is more or less established, more or less integrated, with more or less defined boundaries. This is not a precise set of necessary and sufficient conditions that give "the essence" of a normative order because most of the constituent elements are vague: normativity (or obligatoriness), institutionalization, boundedness, and to use a Llewellynism, groupness are all matters of degree. Often the concept is useful just because it is vague and flexible.

Here the concept of culture provides a relevant analogy. It is a commonplace that "culture" is a vague and elusive term. We know that cultures are not static, monolithic, or clearly bounded; cultures change and

28. TwINING, supra note 10, available at http://www.cambridge.org/twining. See TwINING \& MIERS, supra note 13 (discussing the dangers of reifying rules).

29. Samia Bano, Muslim Family Justice and Human Rights: The Experience of British Muslim Women, 2 J. COMP. L. 38, 45-52 (2007). For example, recent research on Muslim communities in Europe has identified a tendency in both academic and policy debates about pluralism to fall into this trap. Dr. Samia Bano, a British Muslim scholar, writes "There is an underlying assumption that spaces occupied by diasporic communities are based upon and can be identified by fixed and discrete notions of culture and religion which define the communities as a whole. My point is that cultural diversity and identity must also be understood as historically fragmented, unstable and contradictory, and in Britain the situation is well illustrated by the heterogeneity of Muslim communities and the multiplicity of meanings of Islam and Islamic jurisprudence and practice." Id. at 45. Bano goes on to suggest that this kind of thinking also pervades even sympathetic discussions of "honour," "the veil," and "arranged" and "forced" marriages with a tendency to use stereotypes that conceal the underlying complexities of conflict, resistance, and diversity within Muslim communities: "The portrayal of Muslim marriage solely in terms of power, control, and coercion is not only misleading but, as data in this study suggests, simply inaccurate. Instead marriage must be understood as a subjective experience of "symbolic meanings" contextualized according to age, ethnicity, and class background as well as religious practice and familial obligations. These variables are interwoven, often contradictory and at times conflict. Yet it is within the context of "entanglement" and contestation that we can explore marriage as a process of change and transformation." Id. at 49. 
intermix; there are dozens of different definitions of "culture."30 Yet we often confidently talk about multi-culturalism and multi-cultural societies, cross-cultural dialogue or communication, cultural blindness, cultural mixing, and so on. It is a useful concept provided that we do not reify it.

\section{Normativity}

We have noted in relation to the concept of pluralism that there is tendency in the literature to slide from the descriptive to the prescriptive. But classical legal pluralism studies tell us almost nothing about the internal or external legitimacy, obligatoriness, or legality of non-state legal orders. Their existence as a social fact has been their main concern. But questions arise at all levels of legal ordering about how coexisting orders should view each other.

In recent years legal philosophers have devoted a great deal of attention to the topic of "the normativity of law." The central question is whether (state) law is by its nature obligatory, binding, authoritative or whether obligations to obey, observe, respect the law are based on contingencies external to the law itself. For example, in a stimulating book Sylvie Delacroix argues that laws are human creations that are obligatory for judges, lawmakers, and citizens "if law is deemed to promote a set of moral and prudential concerns essential to a 'good' way of living together." 31 In other words the normative force of law is itself a creation of the moral aspirations and sense of responsibility of its subjects as members of a community.

This is one of a number of recent anti-positivist or non-positivist theses about the law that ground obligatoriness in the nature of morality. ${ }^{32} \mathrm{I}$ am not here concerned with the validity or persuasiveness of this particular thesis; but three aspects of it stand in sharp contrast to the mainstream literature on legal pluralism: (a) the focus is on the domestic law of a given society; (b) the idea of law is confined to state law; and (c) the standpoint is that of participants in or subjects of that legal system. The question for

30. TWINING, supra note 10, at 78-87.

31. Sylvie Delacroix, Legal Norms and Normativity: An EsSAy In Genealogy xiv (2006). Delacroix states, "Legal normativity is brought about on a daily basis. Whether it be in revolutionary circumstances or in the quotidian need for judges, lawmakers or citizens to confront law's demands with those of morality or prudence, our ability to bind ourselves through law ultimately depends on our capacity to articulate a better way of living together, and to commit ourselves to it. . . . Tracing the truth of moral judgements back to our own social practices not only affects the nature of disagreement; it also dramatically increases our responsibility when as lawmakers, judges, or citizens we 'take the law into our own hands' and confront it with our moral expectations." Id. at 206.

32. $C f$. Nigel Simmonds, LAw AS A Moral IdEA (2007) (arguing that law is best understood by applying philosophical and moral standards). 
them is: what is my responsibility towards my/our legal system? ${ }^{33}$ This stands in sharp contrast to the social fact theory of legal pluralism that (typically) (a) is not confined to nation states, countries, or societies conceived of as units; (b) extends the concept of law to include at least some kinds of non-state law; (c) adopts the standpoint of an observer of legal orders who is external to them, but takes account of the internal point of view of citizens, lawmakers, judges, and other participants.

The divide between these two perspectives is so great that that one is tempted to say that these two kinds of legal theorist are adopting different standpoints and addressing quite different questions - the one concerned with normativity (prescriptive) the other concerned with social fact (descriptive). But juristic debate brushes aside such simplicities. Each side seems to suggest that the position of the other is untenable. Such critics of legal pluralism may acknowledge that legal relations are not confined within the boundaries of nation states or other bounded societies, but nevertheless reject the idea of "non-state law," question any sharp distinction between external and internal points of view and, most important, insist that law is essentially a moral enterprise or idea. In strong versions, descriptive accounts of law are impossible, in that they are misconceived; in weaker versions they are dismissed as trivial and sterile, mere historical or sociological accounts that are not important and are of no interest to legal philosophers. ${ }^{34}$

Such disagreements look like a re-run of familiar debates between positivists and non-positivists resurfacing in the context of discussions of legal pluralism. However, the situation is more complicated than that for two main reasons. First, some supporters of the idea of legal pluralism are non-positivists. $^{35}$ Second, many writers about legal pluralism have normative concerns, both at the level of ideology (opposing "statecentrism") and in relation to practical problems facing policy-makers, judges, legislators, and other participants in legal processes. However, I shall argue that most classical social fact accounts of legal pluralism, like legal positivism, provide little or no guidance on normative issues, other than suggesting that the phenomena are too empirically important to be ignored.

33. Of course, in situations of pluralism some subjects and participants may have dual loyalties.

34. See TwINING, supra note 10 , at 22-23.

35. Emmanuel Melissaris, UbiQuitous Law: Legal Theory and the SPACE for Legal PLURALISM (2009). This author is an interesting example of the first group. He constructs a sustained argument that ideas of legal pluralism and non-state law can be accommodated within non-positivist legal theory on the basis of people's shared experiences and sense of law that are to some degree universal. 


\section{LEGAL PLURALISM}

\section{A. Mainstream Literature on Legal Pluralism}

There have been several useful surveys of the rich literature on legal pluralism. ${ }^{36}$ I shall not attempt to go over that ground. Sometimes such surveys are a bit schematic, for example distinguishing between classical, modern, and post-modern studies. Most are assigned to legal anthropology and socio-legal studies. The history is more complicated than that. The most cited scholars, Ehrlich, Malinowski, Llewellyn and Hoebel, Griffiths, Chiba, Vanderlinden, Pospisil, Moore, Arthurs, Ellickson, Santos, Tamanaha, Eric Posner, and Menski, do not belong to a single intellectual tradition, even if they have shared interests in social norms and unofficial law. ${ }^{37}$ However, I shall argue that running through nearly all of the "classical" literature is a positivist ideal type, that I shall call "the social fact" view of legal pluralism.

While the anthropological and socio-legal literature on legal pluralism has been in the foreground of most discussions about the subject, there are some other relevant strands. First, historians have long recognized the coexistence of multiple legal orders in medieval Europe, the Ottoman Empire and beyond - almost to the extent that one can argue that from the point of view of world history, the dominance of the nation state and nation-state law has been exceptional, largely restricted to the northern hemisphere for less than two centuries. ${ }^{38}$

Second, pluralism has a long and varied tradition in political science ranging from classic institutionalists, such as Gierke and Hauriou, English pluralists of the twentieth century such as Laski, Figgis, and G.D.H.Cole $;^{39}$ and the rich and varied American empirical tradition that has included

36. See, e.g., Ralf Michaels, Global Legal Pluralism, 5 ANN. REV. L. Soc. SCI. 243 (2009); Brian Z. Tamanaha, Understanding Legal Pluralism: Past to Present, Local to Global, 30 SYDNEY L. REV. 375 (2008) [hereinafter Tamanaha, Understanding Legal Pluralism]; Sally Engle Merry, Legal Pluralism, 20 J. L. \& Soc. 869 (1988); Tamahana, Folly of Social Scientific, supra note 7; Gordon R. Woodman, Ideological Combat and Social Observation: Recent Debate About Legal Pluralism, 42. J. Legal Pluralism and Unofficial L. 21 (1998); Ihsan Yilmaz, Muslim Laws, Politics, and Society in Modern Nation States: Dynamic Legal Pluralisms in England, Turkey and PAKISTAN (2005).

37. Many of these authors are cited within this paper. See, e.g., LLEWELLYN, infra note 71; Griffiths, supra note 16; ARTHURS, infra note 121; ELLICKSON, infra note 44; DE SOUSA SANTOS, infra note 54; Tamanaha, supra note 36.

38. See, e.g., Walter Ullman, The Medieval Idea of Law as Represented by Lucas de Penna: A Study in Fourteenth-Century Legal Scholarship (Gaunt Inc. 1999) (1969); Martin VAN CREVEld, THE Rise AND DeCline OF THE STATE (1999).

39. See, e.g., The Pluralist Theory of the State: Selected Writings OF G.D.H. Cole, J.N. FigGiS, AND H.J. LASKI (Paul Q. Hirst ed., 2d ed., 1993). 
scholars as different as Arthur Bentley (1908), ${ }^{40}$ David Truman (1951), and Robert Dahl (e.g., 1961). ${ }^{42}$ There seems to have been remarkably little interaction between the mainstream political science and socio-legal literatures about pluralism, at least until recently, despite a shared concern (some would say obsession) with state centralism. ${ }^{43}$ However, the extension of the idea of legal pluralism to a wide variety of phenomena may be changing that.

Since about $1990,{ }^{44}$ legal pluralism has become fashionable in several disciplines, although not always under that label. International lawyers, concerned about the fragmentation of international law, have begun to speak in these terms. ${ }^{45}$ Law and economics, in Ellickson's phrase has "discovered social norms" relatively recently. ${ }^{46}$ The elusive idea of "soft law" is increasingly bandied about, for example in studies of European Community law, human rights, international law, corporate self-regulation, and international trade. ${ }^{47}$ Pluralism is a central concept in studies of diffusion or transplantation of law. ${ }^{48}$ In preparing this lecture, I have attempted to sample the massive proliferating literature of the past 15 to 20 years. I have come away feeling that it is little better than a morass.

40. See, e.g., Arthur S. Bentley, The Process of Government: A Study of Social PRESSURES (Transaction Publishers 1995) (1908).

41. See, e.g., David B. Truman, The Governmental Process: Political Interests and PUBLIC OPINION (University of California Press 1993) (1960).

42. See, e.g., Robert A. DAhL, Who Governs? Democracy AND Power in AN American CITY (2d ed. 2005).

43. Pluralism in a different, but related, usage has attracted the attention of students of multiculturalism.

44. See, e.g., Merry, supra note 36 (noting, in 1988, the growing significance of "globalization"); Robert C. Ellickson, Order Without Law: How Neighbors Settle Disputes (1991). (the classic work on Shasta County, California provided a bridge between anthropological studies and economic analysis).

45. See, e.g., SAmantha BeSson, How International is the European Legal Order? Retracing Tuori's Steps in the Exploration of European Legal Pluralism, 5 No FoundATIONS J. OF EXTREME LEGAL PositiviSM 50 (2008); Paul Schiff Berman, From International Law to Law and Globalization, 43 Colum. J. TRAnSNAT'L L. 485 (2005); Andreas Fischer-Lescano \& Gunther Teubner, RegimeCollisions: The Vain Search for Legal Unity in the Fragmentation of Global Law, 25 MiCH. J. INT'L L. 999 (2004); William W. Burke-White, International Legal Pluralism, 25 Mich. J. INT'L L. 963 (2004).

46. Robert C. Ellickson, Law and Economics Discovers Social Norms, 27 J. LEGAL STUD. 537 (1998) (discussing work by Richard McAdams, Robert Cooter, and "the New Chicago School").

47. See TwINING, supra note 10, at 117-18 (discussing uses of "soft law" and its deficiencies as an analytical concept).

48. For more on the "blank slate fallacy," see TwINING, supra note 10, at 285-86. 
This recent expansion, sometimes loosely referred to as "global legal pluralism, ${ }^{49}$ is largely, but not entirely, attributable to globalization. A crucial question is whether this represents an extension of the mainstream socio-legal tradition or whether it represents a qualitatively new departure, even a new "paradigm." ${ }^{50}$ Before addressing this question, it is necessary to identify a "mainstream." The literature on legal pluralism is very diverse. It is dangerous to generalize about it, given the variety of its intellectual roots. Nevertheless, it is possible to construct an ideal type of one important strand, "social fact legal pluralism," which can provide a starting-point for contrasting some of the recent literature. The next section outlines this and uses a series of brief case studies to illustrate some distinctions that are increasingly under attack in the context of globalization.

\section{B. Social Fact Conceptions of Legal Pluralism: An Ideal Type}

Puzzles about the concept of law, positivism, and other general issues in normative and legal theory are an unavoidable part of the backdrop of the study of legal pluralism. The topic becomes significant when one adopts a broad conception of law and treats concepts such as institutionalized normative orders or systems or sets of rules as meaningful. From that perspective legal pluralism is a normal and near-universal phenomenon. I suggest that we can construct a robust social fact view of legal pluralism as an ideal type to which most, but not all, socio-legal studies of pluralism approximated up to about the mid-1990s based on the following points:

1. That if one adopts a broad, positivist, conception of law, legal pluralism is as much a social fact as normative pluralism. Accordingly, it is quite misleading to talk of "legal pluralists" as a marginal school or sect or a particular theoretical perspective. ${ }^{51}$

2. It is important to distinguish between state legal pluralism (sometimes called weak legal pluralism), legal polycentricity (the eclectic

49. See, e.g., Paul Schiff Berman, Global Legal Pluralism, 80 S. CAL. L. REV. 1155 (2007). Most of the phenomena discussed under this heading are clearly sub-global, i.e., not nearly as widespread as the term suggests.

50. Cf. Michaels, supra note 36 , at 244. Michaels states, "The core question for this newly emerging concept of global legal pluralism is whether it constitutes a mere continuation of traditional legal pluralism - perhaps a mere broadening of focus that now includes transnational, supranational and international law in the mix of legal orders it looks at — or whether it is something qualitatively new." Id.

51. von Benda-Beckmann, supra note 7 , at 72-74. This is one of the best socio-legal articles on legal pluralism. I am in general agreement with the thrust of the argument. 
use of sources within different sectors of one state legal system), ${ }^{52}$ and legal pluralism conceived as the coexistence of two or more autonomous or semi-autonomous legal orders in the same time--space context. ${ }^{53}$

3. Legal pluralism is pervasive in all multicultural societies, which in today's world means most societies.

4. Legal pluralism is not new. Indeed, from the perspective of world history, the near monopoly of coercive power by a centralized bureaucratic state is a modern exception, largely confined to the northern hemisphere for less than 200 years.

5. Acknowledging legal pluralism as a social fact involves no necessary commitment to any of the following propositions:

a. that state law is unimportant;

b. that the state is withering away;

c. that acceptance of legal pluralism as a fact involves a denial or weakening of such ideals as liberal democracy, human rights and the rule of law. ${ }^{54}$

6. That it is a distortion to think of interlegality - relations between coexisting legal orders - as being typically one of conflict and competition. How such orders interact and interrelate is an empirical question covering a range of possibilities including symbiosis, subsumption, imitation, convergence, adaptation, partial integration, and avoidance as well as subordination, repression, or destruction. ${ }^{55}$ Interlegality is best viewed as a dynamic process rather than in terms of static structures.

\section{Case Studies}

Here it is useful to look at some concrete examples that illustrate certain recurrent distinctions regularly made within the social fact tradition.

(a) One day in 1957 a train ploughed into a herd of cattle crossing the railtrack in a plain in the western Sudan, killing about 80 head of cattle and injuring others. The victims belonged to the family of the Arab herdsmen

52. Id.

53. The literature on legal pluralism sometimes refers to plurality of sources of law or of arguments, plurality of centers of law creation, plurality of sets of rules and so on. However, the main focus of social fact pluralism is on institutionalized normative orders, i.e., fairly large scale phenomena.

54. See Boaventura de Sousa Santos, Toward a New Common SEnSE: Law, Science And Politics in the Paradigmatic Transition 89-90 (2d ed. 2003); Denis J. Galligan, Law in MODERN SOCIETY 175-88 (2007).

55. Tamanaha, Understanding Legal Pluralism, supra note 36 (emphasizing conflict as being the most problematic aspect, but recognizing that there are other kinds of relations between normative orders.) I am inclined to use the concept of interlegality as an open-ended concept that refers to all kinds of relations - what these are in any given context is an empirical question. 
who were looking after them. ${ }^{56}$ Some six or seven herdsmen ran towards the driver and after arguing with him, some of them speared him to death. The Major Court (trial court) acquitted five of the six accused but convicted one (A1) of murder under the Sudan Penal Code. On appeal he pleaded that he was "deprived of the power of self-control by grave and sudden provocation" under s.249(1) which defined the offence of culpable homicide not amounting to murder. The Sudan Penal Code was based on the Indian Penal Code which in turn was based on English criminal law. The defense of provocation was rejected at first instance, but on appeal the Chief Justice, Mohammed Abu Rannat, reduced the finding of murder to culpable homicide. He dismissed the suggestion that damage to property can never ground a defense of provocation in homicide. ${ }^{57}$ The test was the English test of the reasonable man - in this instance the question was whether the accused had behaved reasonably according to local community values ${ }^{58} \mathrm{He}$ explicitly distinguished the case of the owner of a brand new Cadillac killing the driver of a lorry who accidently destroys it in a collision. ${ }^{59}$ The Chief Justice did not invoke customary law, rather he referred to local rural values in applying the imported English concept of the reasonable man to interpreting a Sudan statute. According to orthodox interpretations, this was not an example of legal pluralism. It looks like a fairly straightforward example of statutory interpretation, perhaps an example of "a cultural defence" in municipal law.

(b) The Otieno burial saga. Another, more famous case illustrates the phenomenon of state legal pluralism, that is the recognition by a state legal system of religious or customary or other law for limited purposes. In 1986-87 the people of Kenya were enthralled, agitated, and divided by a dispute over the burial of a well-known local lawyer. The S.M. Otieno case

56. Sudan Government v. El Baleila Balla Baleila and Others, SUDAN L.J. \& REP. 12-14 (1958). The report does not relate whether they belonged to one of the semi-nomadic pastoralist peoples of the Western Sudan for whom cattle have a symbolic and spiritual value far beyond their utility as wealth and as a source of milk and meat. For a discussion on the significance of cattle among the Nilotic (nonArab) Dinka, see Francis Deng, The Cow and the Thing Called "What": Dinka Cultural Perspectives on Wealth and Poverty, 52 J. INT'L AFF. 101 (1998), reprinted in HUMAN RIGHTS: SOUTHERN VOICES: FRANCIS DENG, ABDULLAHI AN-NA’IM, YASH GHAI AND UPENDRA BAXI (William Twining ed., 2009).

57. The Chief Justice gave the accused the benefit of the doubt in respect of a possible cooling off period and discounted the fact that a relative of his may have been injured by the train. Sudan Government, supra note 56, at 13.

58. The Chief Justice stated, "The reasonable man referred to in the textbooks is the man who normally leads such a life in the locality and is of the same standard as others. . . The real test is whether an ordinary Arab of the standard of A1 would be provoked or not." Id. at 13-14.

59. Although the report is not explicit on the matter, there is an implicit contrast between an unsophisticated nomadic herdsman, for whom cattle have great cultural significance, and a well-to-do urbanite ". . . who knows much about the world." Id. at 14. 
became the Kenya equivalent of the O.J. Simpson case. ${ }^{60}$ Again the facts were relatively simple. In December 1986, S.M. Otieno (known as "SM"), a leading criminal defense advocate, collapsed and died in the garden of his property in Karen, a suburb of Nairobi. His widow had begun to make arrangements for his funeral and burial in Karen, when members of SM's clan intervened claiming that they had the right under Luo customary law to bury their kinsman in his birthplace, Nyalgunga - which they claimed was his real "home." 61 They argued that the clan had the right and the responsibility to decide on where and how the body of a clan member should be buried. The body was kept on ice in the mortuary for over six months while the dispute was litigated in three different courts. First, Otieno's widow, Wambui Otieno, obtained an ex parte order entitling her to bury the body in Karen. The judge, Mr. Justice Shields, re-affirmed his order, denying that the clan had locus standi. His main reason was that the deceased was a metropolitan and cosmopolitan lawyer who had evolved or opted out of Luo customary law. The advocate for the clan appealed to the Court of Appeal, who quashed the order and referred the matter back to the High Court. ${ }^{62}$ After a trial lasting sixteen days, involving complex issues of both fact and law, Mr. Justice Bosire found in favor of the clan on the basis that the deceased intended to be buried in his ancestral "home." After a further three months of legal maneuvers and argument the Court of Appeal found for the clan and dismissed the appeal by a 2-1 majority.

At first sight, this looked like a routine case involving a choice between imported English law and Luo customary law. If the deceased had made a will, it would have been governed by Kenya's Succession Act; but he failed to do so, and there was conflicting evidence about his wishes, which the Court of Appeal ruled were irrelevant. But from the start the case took on a highly emotive political dimension. First, the two judges who ruled for the widow were white, whereas Mr. Justice Busire and the majority in the Court of Appeal were Kenyan Africans. Related to this,

60. The best contemporary source is S. M. Otieno: Kenya's Unique Burial Saga (Sean Egan ed., 1987) (compiling a rich collection of extracts from the contemporaneous reports by the Daily Nation newspaper) [hereinafter Burial Saga]. The case attracted a great deal of public attention at the time and has since generated an extensive literature. See, e.g., THE S.M. OTIENO CASE (J.B. Ojwang \& J.N.K. Mugambi eds., 1989), David William Cohen \& E.S. Atieno Odhiambo, Burying SM: The Politics of KNowledge And the Sociology of Power IN AfricA (1992); John W. Van Doren, Death African Style: The Case of S. M. Otieno, 36 AM. J. Comp. L. 329 (1988). See also Ambreena Manji, Of the Laws of Kenya and Burials and All That, 14 L. \& LiTERATURE 463 (2002).

61. A great deal was made in the case about the meaning of "home" in this context.

62. Virginia Edith Wambui Otieno v. Joash Ochieng' Ougo and Omolo Siranga, (1987) 1 K.L.R. (G. \& F.) 948 (Kenya), reprinted in EugENE COTRAN, CASEBOOK ON KENYA CUSTOMARY LAW 331-45 (1987). 
many perceived this as a clash between local African law and imposed colonial law. ${ }^{63}$ However, it also was seen as a tribal conflict, in which a Kikuyu woman was being subjected to patriarchal Luo law. Arguments about whether and how an individual could opt out of customary law were hotly debated. And there was, of course, a feminist dimension. Luo customary law appeared to give the widow no say in her husband's burial (though this is probably too simple) and Wambui's appeal to Kenya's rather weak constitutional protection of gender equality was rejected. There were disagreements about both the substance of common law and Luo law applicable to the case and some of the family undiplomatically went so far as to suggest that some aspects of Luo custom relating to burial and the treatment of widows were repugnant, that is to say contrary to "justice, equity and good conscience." Thus the case involved clashes of interest and values not only between imported "colonial law" and customary law, but between rural and urban values, gender equality and patriarchy, individualism and communitarianism, ${ }^{64}$ tradition and modernization, and, perhaps most significant in Kenya, between Kikuyu and Luo. In the aftermath, not only was a quite large literature generated, ${ }^{65}$ but inter-tribal engagements were broken off, many more wills were written, and the place of customary law in the national legal system generally became a matter of strong political contention. Shortly after the case, John Khaminwa, counsel for the widow and a well-known critic of the government, was awarded an honorary degree by Haverford College for his contribution to civil liberties. The immediate response of President Moi was to take the unprecedented step of appointing counsel for the clan (Richard Kwach) directly to the Court of Appeal, proclaiming in effect: "Let foreigners reward those who support colonial institutions; Kenya rewards its own."

The Otieno case richly illustrates the dilemmas of a newly independent African country in developing institutions that are suited to local circumstances and conducive to orderly social change and national unity. However, it is also not an example of legal pluralism in the anthropological or socio-legal sense. The national legal system is "pluralistic" in the sense that it recognizes some religious and customary

63. COTRAN, supra note 62, at 344. The Court of Appeal refused to treat this as a choice between customary law and common law, arguing that both are complementary strands in the national law of a unified Kenya: "We can, therefore state that in the course of developing a jurisprudence which will ultimately have a Kenya identity, the courts are enjoined to turn to African customary law as well as to the applied common law, to the decisions of the English courts and courts of Commonwealth countries." Id.

64. Van Doren, supra note 60, at 346-47.

65. See supra note 60. 
law, mainly as personal law for quite restricted purposes. The case was litigated in official courts and argued within a framework of a notionally unified municipal legal system. Indeed, the Otieno case is a reminder that state legal pluralism is not unimportant or uninteresting as some socio-legal scholars have suggested. ${ }^{66}$

(c) Pasagarda law. Boaventura de Sousa Santos uses the term "Pasagarda law" to refer to the institutions and processes concerning housing and other matters dealt with by the Residents' Association ("RA") in an urban settlement (favela) in Rio in the 1970s. ${ }^{67}$ The Residents' Association was a community-wide, democratic social action agency founded in 1966 under a quite formal constitution. It is a nice example of "squatters' law" contrasted with, but sometimes echoing and imitating, "the asphalt law" of the state system. Ironically, although its members were officially trespassers, the main work of the RA was concerned with property relations, involving housing, such as leases, inheritance, and transfer of property. ${ }^{68}$ So Pasagarda law might be interpreted as an illegal legal order. It is a relatively clear example of an institutionalized normative order oriented towards ordering internal relations within a community that largely fell outside the reach of the state legal system. The Residents' Association maintained a cautious arms-length relationship with the police and was, it seems, largely tolerated by state officials. Santos's case study is widely regarded as a classic example of legal pluralism-an institutionalized and stable normative order governing important social relations in a law-like way coexisting with, but separate from, state law.

(d) "The Common Law Movement," as described by Susan Koniak and a few others is the "legal" arm of the militias in the United States. ${ }^{69}$ It

66. John Griffiths, What is Legal Pluralism?, 24 J. Legal Pluralism And UnOfFicial L. 1, 7 (1986). Griffiths labelled state legal pluralism as weak legal pluralism. In the context of critiques of "state centrism," the distinction is important on the ground that it ignores or excludes non-state law. But, as we shall see, from a global perspective a sharp distinction between "official" and "unofficial law" cannot be sustained, for example, in relation to lex mercatoria.

67. DE SOUSA SANTOS, supra note 54, at 99. The situation has changed significantly since Santos wrote about it. See, e.g., Eliane Botelho Junquiera \& Jose Augusto de Souza Rodrigues, Pasagarda revisitada, 12 Sociologia Problemas Practicas 9-17 (1992); Arnoldo Moraes Godoy, Globalization, State Law and Legal Pluralism in Brazil, 50 J. OF LEGAL PLURALISM AND UNOFFICIAL L. 61 (2004). For more information on "illegal cities," see ILlEGAL CiTIES: LAW AND URBAN CHANGE IN DEVELOPING COUNTRIES (Edésio Fernandes \& Ann Varley eds., 1998).

68. DE Sousa SANTOS, supra note 54, at 123. One of the interesting aspects of Santos's study of the imitation and borrowing of concepts and forms borrowed from state law, but adapted to the special context. For example, the term benfeitoria was used in a quite different sense in Pasagarda and the official legal system.

69. Susan P. Koniak, When Law Risks Madness, 8 CARdozo StUd. IN L. \& Literature 65 (1996); Susan P. Koniak, The Chosen People in our Wilderness, 95 MiCH. L. REV. 1761 (1997); Phillip A. Hendges, An Analysis of: People, For Michigan Republic, Ex Rel V. State of Michigan, $30 \mathrm{~J}$. 
fits the category of an institutionalized normative order oriented to ordering relations both within these outlaw communities and with the outside world. "Common law courts" have been set up in many states, "freemen" do not recognize federal and state law for most purposes (including tax, social security, driving licenses), and their activities (including harassment of officials) have from time to time been a matter of concern for state judges and law enforcement agencies. The Common Law Movement has a developed ideology and body of doctrine much of which is expressed in a legalistic form of discourse derived from traditional common law concepts. More than the Pasagarda Residents' Association it defines itself in opposition to municipal law. It challenges the legitimacy of most U.S. federal and state law-with a few exceptions, including bizarrely the Uniform Commercial Code. It is an interesting example of a not insignificant phenomenon that has been largely ignored, indeed almost "invisible," except to state judges and enforcement officials. Over several years of teaching in Florida I have not encountered an American law student who had even heard of it, let alone studied it prior to my course. ${ }^{70}$ If it warrants the label "law," it is in the view of some a rare example of "a crazy legal order."

(e) Pluralist discourses: Kenya and Indonesia. Common lawyers are familiar with the notion of "normative ambiguity" - the coexistence of two apparently competing sets of norms within a single system: Karl Llewellyn's account of the rules of statutory interpretation in terms of two parallel columns of thrust and parry is perhaps the best known; ${ }^{71}$ there are similar accounts by Lasswell and McDougal and the leading English commentator on statutory interpretation, Francis Bennion. ${ }^{72}$ On a broader scale the coexistence of law and equity is sometimes presented as an example of the phenomenon.

MARSHALL L. REV. 937 (1997). For further references, perform an internet search for "Common law movement militias."

70. See TwINING, supra note 10, at 312-16 (discussing invisible and unnoticed legal orders).

71. See, e.g., Karl N. Llewellyn, The Common Law Tradition: Deciding Appeals 522-35 (William S. Hein and Co., 1996) (1960); Karl N. Llewellyn, Remarks on the Theory of Appellate Decision and the Rules or Canons about How Statutes are to be Construed, 3 VAND. L. REV. 395 (1950). See also William Twining, KARL LlEWELlyn AND THE REALiST Movement 159-61 (Oklahoma University Press 1985) (1973) (discussing "normative ambiguity"); TwINING \& MIERS, supra note 13, at 244 (discussing how, on a broader scale, the coexistence of law and equity is sometimes presented as an example of the phenomenon).

72. See, e.g., Myres McDougal \& W. Michael Reisman, International LaW Essays: A Supplement to International LaW in CONTEMPorary Perspective (1981); F. A. R. Bennion, Understanding COMMON LAW LEgISLATION: DRAFTING AND INTERPRETATION (2001). See also JULIUS STONE, LEGAL SYSTEM AND LAWYERS' REASONINGS 254 (1964) (discussing how “competing versions of a legal category are a normal feature of the authoritative materials [of the common law]"). 
A well-known anthropological anecdote in East Africa concerned the naive reaction of a researcher observing the dispute processes of a coastal group who regularly invoked two, well-established sets of norms: one claimed (not always convincingly) to be rooted in tradition, the other in religion. $^{73}$ Typically in group decision-making processes respecting such matters as marriage formation, inheritance, and family disputes, one party (and his supporters) invoked "traditional" norms, the other invoked Islamic ones. The outcomes bore some connection with the norms, but there was no obvious pattern of lexical priority or choice of norm rules. When asked why the group did not simplify their social life by deciding which body of norms had priority or by integrating the two sets into a single consistent code, the response was amazement: "How could we possibly proceed if we had only one body of rules?" As one of my students remarked, the observer's question was perceived to be rather like asking: "Why don't they decide which is the best football team before the start of the season?"

Recently anthropologists have focused on discourse and modes of reasoning that may not be confined to particular arenas. For example, John Bowen has provided some rich illustrations about public reasoning in relation to local disputes in Akeh in Indonesia in both official courts and informal processes. He shows how one can weave into a single argument not only appeals to three distinct bodies of legal rules - adat, shari'a, and state law - but also arguments about the relations between these norms and internal differences of interpretation within these different traditions. ${ }^{74}$ Typically the point is not to choose a specific norm or construct a hybrid one to apply to a fact situation, but to reason towards an acceptable, typically negotiated, resolution of the problem. ${ }^{75}$ Similarly, to be on the safe side, a careful user of law will try to satisfy several constituencies by conforming to all of them, for instance by going through two or three separate ceremonies of marriage.

(f) Religious minorities in Europe. The rapidly expanding legal literature on religious and ethnic minorities in Europe ${ }^{76}$ documents the phenomena of Muslims and others sometimes giving priority to their own customs and religious norms, sometimes adjusting to state law, sometimes

73. I have heard this story several times, but have seen no published version. It possibly relates to the Giriama people of the Coast Province in Kenya, but I am unable to confirm this.

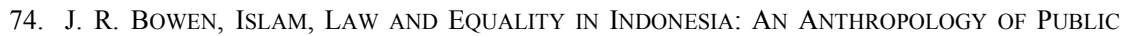
REASONING (2003).

75. See id. at 27-35, 253-61.

76. See, e.g., Migration, Diasporas And Legal SyStems In Europe (Prakash Shah \& Werner Menski eds., 2006); SHARI'A IN THE WEST (Rex Adahar \& Nicholas Aroney eds., forthcoming June 2010); Re-Imagining the Shari'A: Theory, Practice, and Muslim Pluralism at Play (2009), available at http://www2.warwick.ac.uk/fac/soc/law/events/globalsharia/. 
navigating skillfully between alternative sets of norms and institutions, sometimes using different sets of norms as argumentative resources in internal debates and in different state and non-state arenas. Conversely, the existence of such minorities raises a range of practical issues for judges, officials and policy makers and for members of minorities as citizens.

These case studies give the flavor of the mainstream socio-legal literature and illustrate a number of basic concepts and distinctions. Most commentators would probably agree that the Balla Baleila case is not an example of legal pluralism, but rather of competing interpretations of a criminal statute. Similarly, the Otieno case, as suggested above, is an example of state legal pluralism (what Griffiths called "weak legal pluralism"). ${ }^{77}$ John Bowen's account of public reason in Indonesia is on the borderline. It is an excellent example of modern anthropological concern with modes of discursive reasoning, but it refers to reasoning both within and outside a state legal system. Pasagarda law, the Common Law Movement, and institutionalized social and religious practices and customs within ethnic and religious minority communities in Europe are conventionally treated as examples of legal pluralism, insofar as they exemplify discrete institutionalized normative orders that are relatively separate from the law of the state. Recent studies of legal pluralism in Western countries (e.g., the Common Law Movement, studies of Muslim minorities in Europe, and Ellickson's account of Shasta County in California), ${ }^{78}$ underline the point that legal pluralism so conceived is not solely a colonial or post-colonial phenomenon. It exists in all multi-cultural societies, including our own.

However, social fact legal pluralism studies also tend to interpret its scope quite narrowly. For example, they treat different schools of statutory or constitutional interpretation, choice of law rules in conflict of laws (international and domestic), polycentricity, ${ }^{79}$ and forum shopping within a single legal order as not being examples of legal pluralism stricto sensu.

\section{Conceptualizing "the legal"}

Mainstream socio-legal and anthropological studies of legal pluralism up to the mid-1990s tackled a wide range of phenomena from a variety of

77. See generally BURIAL SAGA, supra note 60.

78. For more information on the Common Law Movement, see supra note 69. For more information on Muslim practices in Europe, see supra note 76. For information on Shasta County, see ELLICKSON, supra note 44.

79. See, e.g., Legal Polcycentricity: COnSEQuences of Pluralism In LaW (Hanne Petersen $\&$ Henrik Zahle eds., 1995) (referring to the eclectic use of sources in different sectors of one legal system). 
perspectives. There is a rich heritage of particular studies, some rather unsatisfactory theorizing, and some even more unsatisfactory polemics.

Unfortunately, the subject was bedeviled by a long-running controversy about how to conceptualize the "legal" in "legal pluralism." These concerns were shared by some of the leading theorists in the field. For example, in 1988 Sally Merry argued that "calling all forms of ordering that are not state law by the term law confounds the analysis"; 80 in 1993 Brian Tamanaha wrote of "the folly" of a "social scientific" concept of legal pluralism; ${ }^{81}$ and Simon Roberts, a respected legal anthropologist, has written repeatedly "against legal pluralism." 82 I have argued at length elsewhere that the problem of "the definitional stop"- - where to draw the line between legal and non-legal phenomena-is susceptible to workable and sensible solutions in particular contexts. ${ }^{83}$ At least for most purposes of empirical study, nothing much turns on where or even whether one sets boundaries to the legal, provided that one recognizes that phenomena designated as unofficial law or non-state law or law-like normative orders deserve our attention as jurists as an essential part of understanding law. Of course, from the standpoint of state policy-making, and occasionally in adjudication, whether particular social norms or normative orders are officially recognized as "law" can sometimes be of considerable practical importance. $^{84}$

In different ways, John Griffiths and Brian Tamanaha have recently come round to the view that legal pluralism is best seen as a species of normative pluralism. Griffiths, a leading pioneer in the field, has recently written that the word "law" should be abandoned "for purposes of theory formation in sociology of law." 85 Tamanaha has also freed himself from the obsession with the definitional stop by making this move. He suggests a rough taxonomy of "forms of normative ordering commonly discussed in studies of legal pluralism" ${ }^{\$ 6}$ to include six categories (i) official or positive

80. Merry, supra note 36 , at 878 .

81. Tamanaha, Folly of the Social Scientific, supra note 7.

82. See, e.g., Roberts, supra note 7; Simon Roberts, After Government? On Representing Law Without the State, 68 MoD. L. REV. 1 (2005) [hereinafter Roberts, After Government].

83. See TwINING, supra note 10 , at 88-121, 362-75.

84. See, e.g., Ralf Michaels, The Re-State-ment of Non-State Law: The State, Choice of Law, and the Challenges from Global Legal Pluralism, 51 WAYNE L. REV. 1209 (2005) (discussing how, in some contexts, practical consequences turn on a distinction between law/non-law-most notably in conflicts of laws - but how law is conceived for such purposes depends on the specific context).

85. John Griffiths, The Idea of Sociology of Law and its Relation to Law and to Sociology, in 8 LAW AND Sociology: CurRent Legal Issues 49, 63-64 (Michael Freeman ed., 2005); see also Griffiths, supra note 16.

86. Tamanaha, Understanding Legal Pluralism, supra note 36, at 397. 
legal systems; (ii) customary normative systems; (iii) religious/cultural normative systems; (iv) economic/capitalist normative systems; (v) functional normative systems; (vi) community/cultural normative systems. Of course, Tamanaha still has to distinguish between official legal systems and the rest, but he emphasizes, as I have done over the years, that not much need turn on this distinction. ${ }^{87}$ Indeed, custom, religion, and culture as concepts are widely recognized to be almost as problematic as the concept of law. The distinction between "legal" and "non-legal" looks different in this context. Suffice to say that removing questions about conceptualizing law from the agenda of theorizing about pluralism, opens the way to considering other issues-including switching the focus of attention to concepts of norms and of pluralism.

\section{E. State Centralism}

In 1986, John Griffiths launched a sharp attack on legal centralism, which he treated as an "ideology." In this view "law is and should be the law of the state, uniform for all persons, exclusive of all other law, and administered by a single set of state institutions." 88 This ideology is a mixture of assertions about how the world ought to be and a priori assumptions about how the world actually and even necessarily is. In Griffiths's view, legal centralism was "the major obstacle to the development of a descriptive theory of law." 89

87. Id. at 399-400. See TwINING, supra note 10, at 101-02, 370-71 (explaining my position that the concept of law has acquired too many associations and too much controversial baggage to be useful as an analytical concept, and that what is an appropriate way of conceptualizing law and drawing a workable distinction between legal and non-legal phenomena depends largely on context). Of course, in many contexts there will be borderline cases: often not much turns on their resolution. In some contexts all that is needed is a rough and ready distinction, such as Tamanaha's categories or MacCormick's institutionalized normative order. See NEIL MACCORMICK, INSTITUTIONS OF LAW: AN ESSAY IN LEGAL THEORY ( $2 \mathrm{~d}$ ed. 2008). There could also be a "thin functionalist" definition of law-e.g., that law refers to species of social norms or institutionalized social practices oriented towards ordering (i.e., patterning) relations between subjects ("persons" in a broad sense) at different levels of relations and ordering. See Twining, supra note 10, at 103, 116-21. If one accepts, as I do, that obligatoriness, institutionalization, and efficacy are matters of degree, extending along a range of continuums, the drawing of sharp lines is to some extent arbitrary, but what constitute reasonable judgments of appropriateness can usually be most easily settled in a given context. Haack adopts a similar stance and relates it to Peirce's idea of "synechism." Haack, supra note 9, at 456-611 (stating, "an in-principle preference for hypotheses that posit continuities over those that posit sharp distinctions"). See generally John Finnis, NATURAL LaW And NAtURAL Rights (1980); Marc Galanter, Justice in Many Rooms: Private Ordering and Indigenous Law, 19 J. Legal PluRALISM AND UNOFFICIAL L. 1 (1981).

88. See Griffiths, supra note 66 , at 3 . Griffith's aim was explicitly to establish a descriptive conception of legal pluralism for social scientific purposes.

89. Id. 
Attacks on "legal centralism" and "state centralism" have continued, but the grounds have been diverse. In light of subsequent discussions, the idea of state centralism needs to be disaggregated into a series of distinct, but related, propositions of different kinds:

(a) At the level of description, the state is the only institution that contributes to social order.

(b) The empirical claim that, at least in modern societies, state law is in practice the most important form of law: it is dominant, technically superior, and more powerful than other forms of institutionalized ordering. ${ }^{90}$

(c) The normative claim that the state has sole and supreme authority in a given territory or space and it has a monopoly of the legitimate use of force.

(d) The ideological claim that the state is the best or only hope for the realization of liberal democratic values, such as democracy, equality, human rights, and the rule of law.

Most people who have thought about it would contest (a) as an empirical statement about nearly all societies. Conversely, asserting that legal pluralism is a social fact, involves no general claims about the de facto importance, technical sophistication, and power of modern bureaucratic states (b). Such claims are difficult to test empirically. From a global perspective they are more plausible in Singapore and Sweden than in the Democratic Republic of the Congo or Somalia. ${ }^{91}$ The issue is central to discussions about the decline of the state, not least in the context of globalization, but inquiries about its relative power and importance are extraordinarily elusive. (c) and (d) are both contested, but the issues are complex.

Before considering the normative claims, it is worth noting some particular concerns that have complicated debates about legal pluralism. First, part of the passion behind attacks on state centralism was directed against the view that tribal law or religious law did not deserve to be called "law." This was felt to be patronizing in two ways: it implied the inferiority of so-called "primitive" or "pre-literate" societies and it implied that scholars of Islamic law, Hindu law, or African law were not really jurists. Concern about academic snobbery may seem trivial, but it had a profound effect on academic practice. It is a reasonable complaint that in Western academic traditions, study of non-state law and non-Western traditions, systems, and points of view has been ethnocentrically marginalized.

90. E.g., GALLIGAN, supra note 54, at 173-92.

91. Of course, some Western theorists, such as Ehrlich, Griffiths, and Tamanaha, have argued that the most important norms are non-state ones. 
Conversely, there is a genuine intellectual concern, forcefully articulated by Simon Roberts, that lumping together state law and diverse forms of non-state law, obscures the distinctiveness of centralized forms of governance and lets blinkered lawyers in to view other forms of normative ordering through distorting lenses. ${ }^{92}$ In my view, one can go a long way to meeting this concern by treating state law and non-state law as distinctive species of "law," using the term "state law" in appropriate contexts, and recognizing that most of our Western heritage of theories of law are theories of state law. ${ }^{93}$

Thirdly, underlying most regimes of legal education and training there is a concern about the practical relevance of what is being studied. The maxim "lawyers don't practice non-state law" is sometimes true. It is also self-confirming, but it is being eroded in multicultural societies and in such fields as international commercial arbitration.

Fourthly, even in circles in which legal pluralism is accepted as a significant phenomenon, a milder form of state-centrism prevails. In much of the literature the focus is still very largely on the interactions between the state and non-state law: how the state does and should respond and where it should hold the line, how minority communities should adjust, and how they make their voices heard in policy formation. ${ }^{94}$ There has been much less attention paid to relations between non-state normative orders or what the various religious and other traditions say about what should be the attitudes of citizens and communities, especially minority communities, towards the state. This tendency to focus on the relationship of non-state law to the state is understandable, for issues of policy about how advanced industrial societies should respond to the huge influx of immigrants with diverse cultural and religious backgrounds is among the pressing issues facing Western societies. But, as we shall see, from a global perspective, the focus on problems of Western nation states is doubly parochial in that it ignores other societies and other levels of ordering.

The idea of legal pluralism, and the importance of the phenomenon, is widely recognized in recent scholarly literature. However, it would be wrong to assume that state-centrism is dead. Quite apart from the fact that most Western academic law is focused almost entirely on domestic municipal law of sovereign states, and is likely to remain so, there are

92. Roberts, Against Legal Pluralism, supra note 7; Roberts, After Government, supra note 82.

93. TWINING, supra note 10, at 371-75.

94. Avery Katz, Taking Private Ordering Seriously, 144 U. PA. L. REV. 1745 (1996) (discussing how, after law and economics scholars "discovered" social norms, their focus was very largely on what state policy should be, rather than understanding and guiding systems of private ordering on their own terms or independently of the state). 
fundamental ideological questions about the desirability of many forms of legal pluralism. An interesting example of a moderate form of state centrism is provided by the leading socio-legal scholar, Denis Galligan: he recognizes that there are forms of non-state law that coexist and intersect with state legal orders; he acknowledges that many claims made for the state's social role are extravagant, that it can be ineffective or worse, and that non-state normative orders, whether recognized as legal or not, often have social utility. However, he concludes that the modern democratic state provides the best hope for achieving some social goods, including human rights, the rule of law and democracy. In respect of the subordination of non-state law, he recognizes that there can be semi-independence or semiautonomy, but denies claims to complete autonomy. ${ }^{95}$

Galligan's focus is on state law in modern democratic societies. His account raises a host of empirical questions about the extent to which a given state's claims to ultimate authority are accepted by all groups in a society and the extent to which claims are in fact made for superiority or primacy over state law, for instance by adherents to a particular religion. He also goes further by making some strong normative claims: he asserts that in modern societies state law is dominant, ascendant, superior to, and more important than all other forms ${ }^{96}$ and "modern legal systems are indispensable in modern societies because they add "security to relations between persons, facilitate the provision of services and welfare, enable the regulation of one set of activities to achieve another set of social goods, and control the imposition of punishment." ${ }^{97}$

This raises a range of both normative and empirical issues which extend far beyond the topic of "legal pluralism." Some of these issues concern broad questions of general political theory about the role of the state, its claims to a monopoly of legitimate force, and claims to independence or autonomy by or on behalf of non-state legal orders. The term "state centrism" was coined to criticize tendencies to focus solely on the state, to ignore the existence of non-state normative orders and,

95. GALligan, supra note 54, at 158-70. "It is impossible to accept that families, professional associations, and sporting clubs, among others, are in a strong sense autonomous of state law either legally or socially. ... . [I]ndependence and autonomy occur within the jurisdiction of state law and in relationship to it." Id. at 176-77. Chapter ten forcefully criticizes claims to strong autonomy by nonstate orders, but allows much weaker claims for semi-autonomy or semi-independence. Id. at 173-88. One must, of course, distinguish claims to superiority and monopoly of legitimate force by states from the standpoints of those subject to multiple coexisting orders who do not necessarily accord the state highest priority, for example, a member of a religious minority who places religious precepts above state laws.

96. Id. at 158-61.

97. Id. at 161 . 
especially in colonial contexts, to treat them as inferior. In the context of contemporary debates about relations between the state and religious or ethnic minorities the pejorative associations of the term may be inappropriate. For example, even a culturally sensitive and well-informed interpretation of a principle of non-discrimination or of gender equality will inevitably conflict with some aspects of any religious or customary culture that has patriarchal tendencies. Some will consider it inappropriate to attach the pejorative label "state centrism" to a position that customary or religious social practices should only be recognized by state law if they are compatible with human rights or basic constitutional principles. These are important and complex political issues with wide ramifications. Socio-legal research on legal pluralism can inform debates about them, as it has done recently with regard to ethnic and religious minorities in Europe, but on its own it cannot purport to resolve such fundamental issues of political and democratic theory. In this context, it is important to remember Boaventura Santos' admonition against romanticizing legal pluralism as some scholars have tended to do: "[T]here is nothing inherently good, progressive or emancipatory about legal pluralism." ${ }^{98}$

\section{F. A Non-positivist Challenge}

At this point, I should anticipate an objection. Someone one might say: "I agree that I encounter many different types of rules and norms in my daily life and that what you call 'normative pluralism' can be viewed as a social fact. But it does not follow from this that I need to buy into a concept of legal pluralism nor accept that it is a species of normative pluralism. What if I believe that state law is the only true form of law and that all the other kinds of phenomena usually lumped together by legal pluralists are distinguishable as social norms, or customs, or religious prescriptions, or at best laws by analogy and extension? What if I do not accept a social fact conception of state law, such as that of Hart or Raz or even Kelsen, but lean towards a non-positivist conception such as that of Fuller or Dworkin? ${ }^{99}$ Law is the most contested concept in legal theory and what is at stake is not a matter of simple semantics, resolved by a

98. DE Sousa SANTOS, supra note 54 , at 89.

99. Norman Singer reports discussions with Professor René David, who was responsible for the Ethiopian Civil Code: "He felt that the official law recognized the Civil Code was the only law in Ethiopia ... [when Singer demurred] Professor David simply reaffirmed his belief that there had to be official recognition by the government, and in the case of Ethiopia, since there was no recognition of the parallel system and that in fact, they were not [since customary orders were not a] system of law, there was nothing to recognize even if the government would do it." Norman Singer, The Early Days of the Faculty of Law, AAU, 2 MiZAN L. REV. 137, 144-45 (2008). Of course, the hard line taken by Professor David and others had important practical consequences. 
stipulative arbitrary definition: what is at stake is conceptual coherence, issues of legitimation and legality, and much else besides. And what if my main concern is with practical normative issues? How should the state respond to the coexistence of other normative orders? When should it, through policy, legislation, administrative discretion, or judicial development recognize, reject, incorporate, integrate, subordinate, assimilate, or just ignore non-state legal orders ${ }^{100}$ You cannot just beg these issues."

Here I must confess and avoid. Socio-legal pluralism studies have tended to be conceived quite narrowly and to have few claims to immediate practical relevance. I agree that the objection raises real concerns with practical as well as theoretical implications. One also needs to be careful about projecting this kind of conception of pluralism onto the world stage. A social fact conception of normative pluralism is like a social fact positivist conception of law: it separates off empirical description and explanation from questions of justification, legitimation and evaluation and, if it sidelines such questions, some will say that the inquiry is impoverished. If you treat Pasagarda law or the Common Law Movement or Giriama or Chagga disputing processes and discursive practices as examples of institutionalized normative orders that exist as a social fact it is not necessary to inquire about their validity, legitimacy, justice, or authority. For example, Koniak's account of the Common Law Movement tells us about its history, ideology, and values, without any attempt to legitimate or justify the phenomenon. ${ }^{101}$ An empirical account of such phenomena can draw attention to their existence, describe, interpret, explain, and compare their characteristics, give an account of their interrelationships and interactions, and furnish some useful concepts. But

100. This echoes but extends the excellent discussion in Michaels, supra note 84, mainly from the point of view of choice of law in conflicts of laws, centered on the question: Should choice of law rules ever designate non-state norms as applicable law? Id. at 1210. Michaels has recently argued that many concerns about legal pluralism can be accommodated in "a new conflict of laws, now understood as a general theory of interlegality, as the way in which the law makes sense of its own plurality." Michaels, supra note 36 , at 255 . Because of the earlier antipathy to state centrism, mainstream legal pluralism has tended to ignore conflicts of laws, conceived as a part of municipal law. But, as Michaels suggests, relations between legal orders are to some extent determined by "the politics of recognition." This is a promising line of argument which further challenges sharp distinctions between "weak" and "strong" legal pluralism and between state recognition and "interlegality." Michaels, supra note 84, at 1227.

101. If they exist as social practices, acceptance by the group or those subject to them assumes answers to these questions from an internal point of view (but that raises some conceptual hares about the concept of social practice), but from an external observer's point of view a socio-legal / empirical account typically does not make any assessment of them in relation to political ideology, such as democratic liberalism, or any claims as to how they should be treated by the state as a matter of policy or law or discretion. 
"interlegality" in this context is an empirical, not a normative concept. ${ }^{102}$ And socio-legal accounts of legal pluralism are not very practical. Such empirical accounts may serve some purpose as a preliminary to considering conceptual and normative issues concerning the implications of treating normative and legal pluralism seriously, but beyond that they are not very helpful. $^{103}$

\section{IMPLICATIONS OF GLOBALIZATION}

It has been suggested that the extension of the idea of "legal pluralism" to fields such as international law, human rights, diffusion, regulation, international finance and trade, and comparative law is a consequence of "globalization." 104 That is a simplification. If colonialism, urbanization, and migration are global phenomena, then most of my pre1990 examples could be said to be outcomes of "globalization." However, a new concept, "global legal pluralism" has been given wide currency.

What are the implications of globalization for the study of legal pluralism? By globalization in this context I mean not only economic globalization driven by an ideology loosely linked to free markets and the Washington consensus - what the anti-globalization movement is againstbut all the complex processes that have increased interaction and interdependence across national and cultural boundaries in respect to communications, trade, migration, language spread, epidemics, ecology, security, and so on. ${ }^{105}$ In the present context, one central point is crucial:

102. Haack, supra note 9 .

103. Of course, not all socio-legal studies of legal pluralism have maintained a sharp distinction between is and ought or held back from addressing such normative issues - in the process some of succumbed to the gravitational pull of state centrism, as critics such as Lauren Benton have pointed out. Lauren Benton, Beyond Legal Pluralism: Towards a New Approach to Law in the Informal Sector, 3 Soc. AND LEGAL STUD. 223 (1994).

104. E.g., Michaels, supra note 36, at 243-46. It is important to distinguish three types of claims about "global legal pluralism": (a) that the processes of globalization are creating new forms of legal pluralism (social fact); (b) that it is illuminating to consider the subject of legal pluralism from a global perspective (or "through the lens of globalization"); (c) that there is a new kind of pluralism, namely, "global legal pluralism." These distinctions are sometimes blurred. Compare, for example, the following titles and statements in influential articles: "How is globalization governed? I suggest that it is governed by the totality of strategically determined, situationally specific, and often episodic conjunctions of a multiplicity of sites throughout the world. These sites have institutional, normative, and processual characteristics. The totality of these sites represents a new global form of pluralism." Francis Snyder, Governing Economic Globalization: Global Legal Pluralism and European Law, 5 EUR. L. JO. 334, 334-45 (1999). Contrast this with, “Although 'globalization' is, of course, a controversial term, the idea of law and globalization nevertheless provides a useful lens for viewing the plural ways in which legal norms are disseminated in the Twenty-First Century." Berman, supra note 45, at 485 . Also note the title of Michaels, supra note 84.

105. See William Twining, GLT, supra note 3, at 7-8; Twining supra note 10 , at 13-18. 
interdependence is a relative matter and most so-called processes of "globalization" operate at sub-global levels. There are, of course, genuinely world-wide phenomena and issues, but so far as law is concerned the most significant patterns relate to sub-global phenomena including empires, diasporas, alliances, regions, legal traditions, and important networks - all of which are of special legal significance. Much globalization talk is hyperbole: World War I, the common law world, the Arab world, the English speaking world, the world cup at cricket and the world series at baseball are all sub-global. ${ }^{106}$ As lawyers, we need to be acutely aware of the relativities of proximity and interdependence.

I have also argued at length elsewhere that if we want to construct a balanced perspective on legal phenomena in the world, we need to conceptualize law broadly to include significant examples of non-state normative ordering. ${ }^{107}$ A picture of law in the world that omits Islamic or other religious law, all kinds of custom and customary law, the kinds of "soft law" that exercise scholars of EU law, international law, human rights law, and self-regulation just leaves out too much. This, of course, again raises the problem of the definitional stop: if one moves beyond state law how does one avoid including all kinds of social norms and institutions? ${ }^{108}$

If one adopts a broad conception of law, from a global perspective normative and legal pluralism are almost universal throughout the world. From that perspective, understanding law needs to take account of all major levels of social relations and levels of ordering those relations.

TABLE I ${ }^{109}$

\section{LEVELS OF LAW}

If law is conceived of as a form of social practice concerned with ordering relations between subjects or persons (human, legal, unincorporated, and otherwise) at a variety of levels of relations and ordering, not just relations within a single nation state or society, one way of characterizing such levels is essentially geographical:

global (as with some environmental issues, a possible ius humanitatis) and, by extension, space law (e.g., mineral rights on the moon);

106. For fuller discussions, see TwINING, supra note 10, at 13-18.

107. Id. at 88-116.

108. See TwINING, supra note 10, at 116-21 (my answer is that this depends on context).

109. See TwINING, GLT, supra note 3, at 139. 
international (in the classic sense of relations between sovereign states and more broadly relations governed, for example, by human rights or refugee law);

regional (for example, the European Union, European Convention on Human Rights, and the African Union);

transnational (for example, Islamic, Hindu, Jewish law, Gypsy law, transnational arbitration, a putative lex mercatoria, INTERNET law, and, more controversially, the internal governance of multinational corporations, the Catholic Church, or institutions of organized crime);

inter-communal (as in relations between religious communities, or Christian Churches, or different ethnic groups);

territorial state (including the legal systems of nation states, and sub-national jurisdictions, such as Florida, Greenland, Quebec, and Northern Ireland);

sub-state (e.g., subordinate legislation, such as bye-laws of the Borough of Camden) or religious law officially recognized for limited purposes in a plural legal system; and

non-state (including laws of subordinated peoples, such as native North Americans, or Maoris, or the Romani people or illegal legal orders such as Santos's Pasagarda law, the Southern People's Liberation Army's legal regime in the Southern Sudan, and the Common Law Movement of militias in the United States) ${ }^{110}$

Which of these examples should be classified as "law" or "legal" is essentially contested within legal theory and also depends on the context and purposes of the discourse.

These levels are not stacked in a neat vertical hierarchy from the very local to outer space, for they include sub-global patterns such as empires, legal traditions, and diasporas that cut across such hierarchical neatness. Nor are all levels of relations tied to geographical territory. Religions, beliefs, systems of morality, personal laws, the Internet cannot be simply mapped geographically. ${ }^{111}$

110. With the exception of Romani law, these exist within nation-state boundaries, but typically disclaim that they are "sub-state," if that means hierarchically subordinate.

111. Twining, supra note 10, at 74-76. In considering the implications of globalization for the discipline of law as it is institutionalized in a particular country or region, it is helpful to distinguish between (a) established transnational fields that command increased attention (e.g., regional integration, transnational commercial law, human rights law); (b) new or developing subjects that have strong transnational aspects (e.g., transitional justice, Internet law, environmental law); (c) established fields formerly perceived as domestic that have recently acquired increased transnational dimensions, such as 
In General Jurisprudence I argued that if one adopts a global perspective and a long time scale, at the risk of over-simplification one can discern some general tendencies and biases in Western academic legal culture that are in the process of coming under sustained challenge in the context of "globalization." In a crude form, these can be expressed as a series of simplistic assumptions that are constituent propositions of an ideal type, as set out in Table II:

TABLE II ${ }^{112}$

WESTERN TRADITIONS OF ACADEMIC LAW: SOME ASSUMPTIONS CHALLENGED BY "GLOBALIZATION."

(a) that law consists of two principal kinds of ordering: municipal state law and public international law (classically conceived as ordering the relations between states) ("the Westphalian duo");

(b) that nation-states, societies, and legal systems are largely closed, self-contained entities that can be studied in isolation;

(c) that modern law and modern jurisprudence are secular, now largely independent of their historical-cultural roots in the JudaeoChristian traditions;

(d) That modern state law is primarily rational-bureaucratic and instrumental, performing certain functions and serving as a means for achieving particular social ends;

(e) that law is best understood through "top-down " perspectives of rulers, officials, legislators, and elites with the points of view of users, consumers, victims and other subjects being at best marginal;

(f) that the main subject-matters of the discipline of law are ideas and norms rather than the empirical study of social facts;

(g) that modern state law is almost exclusively a Northern (European/Anglo-American) creation, diffused through most of the world via colonialism, imperialism, trade, and latter-day postcolonial influences;

(h) that the study of non-Western legal traditions is a marginal and

torts, family, and criminal law; (d) the diffusion of religious law and customary practices associated with large scale migration; and (e) the interface with municipal state law in Northern countries of the religious and customary practices of ethnic minorities (both immigrant and indigenous). Most of these examples relate to state law, but globalization also has implications for the diffusion of religion, custom, and other forms of non-state law and for the interaction of state and non-state law at different levels of relations and ordering. Id. at 446-48.

112. TWINING, supra note 10 , at 5-8. 
unimportant part of Western academic law;

(i) that the fundamental values underlying modern law are universal, although the philosophical foundations are diverse. ${ }^{113}$

This list does not claim to be comprehensive. It refers to some general ideas that are recognizable and widespread, but by no means universal, within our legal traditions. It suggests that Western academic legal culture has tended to be state-oriented, secular, positivist, "top-down," Northocentric, unempirical, and universalist in respect of morals. Of course, all of these generalizations are crude and subject to exceptions. Their relevance here is that most of these assumptions have also been challenged in the mainstream anthropological literature about normative and legal pluralism. Thus:

(a) Most writers on legal pluralism have accepted, not without controversy, some conception of non-state law that goes beyond the Westphalian Duo of sovereign state municipal law and classical public international law.

(b) Many commentators have challenged the idea of societies and state legal orders as closed discrete entities that can be studied in isolation. ${ }^{114}$ It is, however, the case that early anthropological studies (post-Malinowski) tended to focus on societies, tribes and peoples in such fashion, but recent work has emphasized the fluidity and porosity of boundaries and the importance of setting local studies in broad historical and geographical contexts. $^{115}$

(c) Most studies of legal pluralism have been based on secular, but not necessarily positivist, social scientific assumptions; but most writers have been well aware of the importance of religion and religious revival in the societies they studied.

(d) Criticisms of "instrumentalism" are a recurrent theme of several leading writers on legal pluralism, including John Griffiths and Brian Tamanaha. ${ }^{116}$

113. TwINING, supra note 10 , at 5-6. Most of these assumptions have been contested within Western traditions of academic law. They are nevertheless sufficiently widespread and familiar to constitute an "ideal type" of significant ideas that are under challenge from "globalization."

114. See TwINING, GLT, supra note 3, at 7-8. See also Twining, supra note 10, at 163-65 (discussing criticisms of John Rawls's treatment of "society" as a self-contained unit).

115. See June Starr \& Jane F. Collier, Introduction: Dialogues in Legal Anthropology, in HISTORY

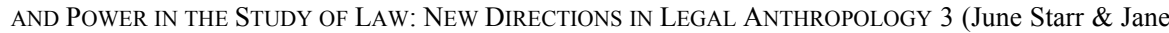
F. Collier eds., 1989) (a conference at Bellagio in the mid-1980s marked a critical turning-point in legal anthropology).

116. John Griffiths, Is Law Important?, 54 N.Y.U. L. REV. 339, 345-51 (1979); TAMANAHA, supra note 87; TwINING, supra note 10, at ch. 16.4, available at http://www.cambridge.org/twining. 
(e) The social-scientific literature on legal pluralism is generally critical of "top-down" perspectives and pays a great deal of attention to the viewpoints and behavior of subjects, victims, entrepreneurs, resisters, users and other forms of social actors. However, Lauren Benton has criticized much of this literature (even when claiming to study legal pluralism "from below"), for maintaining an explicit or lingering implicit adherence to structuralist assumptions that obscure the viewpoints and perceptions of ordinary actors. ${ }^{117}$

(f) Socio-legal studies of legal pluralism have generally not confined their focus to rules and norms, but have emphasized institutions, processes, and action in varying degrees. Writings on colonial legal situations have shown how often what was perceived as "customary law" by officials was an artificial construct, a product of the interaction between colonial officials and local leaders or informants, with the result that attempts to codify custom or administer it in state courts were often far removed from the actual social practices of ordinary people. ${ }^{118}$ This was in large part because code-like statements of customary law distorted the nature and meaning of the phenomena when abstracted from the processes in which they operated. ${ }^{119}$

(g) Western comparative law and accounts of transplantation or diffusion of laws have tended to see the process patronizingly in terms of the exportation of legal concepts, rules and ways of thought from "parent" modern state legal systems to "primitive," "traditional," underdeveloped, or adolescent state importers whether by way of imposition, negotiation or voluntary adoption. Much of the literature of legal pluralism recognizes that the processes of diffusion of law are much more varied and complex than that image suggests, involving multiple pathways, varieties of agents, and almost inevitable interaction with pre-existing normative orders or regimes, involving resistance, rejection, adaptation, and so on. ${ }^{120}$

117. Benton, supra note 103, at 236-37.

118. See, e.g., Martin Chanock, Law, Custom And Social Order: The Colonial EXPERIENCE IN MALAWI AND ZAMBIA 48-57 (Heinemann 1998) (1985).

119. William Twining, The Restatement of African Customary Law: A Comment, 1 J. MoD. AFr. STUD. 221 (1963). Cf. CHANOCK, supra note 118, at 62 (stating, "The essence of customary systems may be said to have lain in the processes, but these were displaced, and the flexible principles that guided them were now fed into a rule-honing- and using machine operating in new political circumstances.") For a robust defence of the Restatement of African Law project when subjected to such criticism, see Eugene Cotran, The Place and Future of Customary Law in East, 5 Commonwealth Law SERIES 72 (1966); A. N. Allott, The Hunting of the Snark or The Quest for the Holy Grail: The Search for Customary Law, in COMPARATIVE LAW In GlOBAL PERSPECTIVE (Ian Edge ed., 2001).

120. See TwINING, supra note 10, at 269-92. 
(h) Insofar as Western academic law tended to ignore or marginalize law in non-Western societies, the reverse was true of the literature of legal pluralism which was in large part stimulated by and focused on law in colonial and post-colonial societies.

(i) Finally, much of the underlying ideology of Western legal theory is universalist in tendency - natural law, utilitarianism, democratic liberalism, and human rights theory, for example - whereas anthropologists and sociolegal scholars have tended to emphasize the importance of local conditions and culture and to be generally more sympathetic with at least the weaker forms of cultural relativism.

Thus of my nine points at which doubt has been cast on widespread assumptions of mainstream Western academic law, nearly all have been challenged or only weakly adhered to in mainstream socio-legal studies of legal pluralism. They are more in harmony with a global perspective than many other fields of legal scholarship. However, it would be dangerous to assume that this means that mainstream legal pluralism concepts and insights are immediately transferable to the new fields of inquiry that are opened up by adopting a global perspective. Let me mention five points at which there is a need for caution:

First, a great many social fact pluralism studies have focused on relatively small, face-to-face groups. ${ }^{121}$ Second, the main emphasis has been on what in our legal tradition has been classified as private lawmarriage, family, inheritance, land, and to a lesser extent wrongs or obligations. Until recently, much less attention has been paid to commercial and economic law, migration, governance structures, criminal law, and human rights. Again, there are notable exceptions. Third, and perhaps most significant, nearly all mainstream studies have focused on sub-state or sub-national phenomena within a single country. ${ }^{122}$ Fourth, much is made of the diversification of significant actors in international relations and, to a lesser extent, international law: in addition to states, international organizations, non-governmental organizations, multi-national corporations, peoples, crime cartels, and other groups now strut the global stage. The mainstream studies of socio-legal pluralism have been mainly concerned with individuals, families, clans, or relatively small communities

121. But see Harry W. Arthurs, Without the Law: Administrative Justice and Legal PLURALISM IN NiNETEENTH CENTURY ENGLAND (1985). Arthurs's story of the rise of administrative law (forms of regulation arising largely independently of legislation and judge made law) is a notable exception and it is not a coincidence that he is one of the leading legal scholars to have made the transition to a global perspective.

122. A rare exception was Walter Weyrauch's transnational studies of Romani ("gypsy”) law. See, e.g., GYPSY LAW: ROMANI LEGAL TRADITIONS AND CULTURE (Walter O. Weyrauch ed., 2001). 
or groups. Fifth, and perhaps less obvious, legal pluralism studies did not break very far away from a weak form of state centrism: a great deal of the attention has been focused on the relations and interaction between nonstate legal orders and the state. This includes not only studies of the responsiveness or otherwise of state legal systems, but also stories of resistance, "customary law" as a hybrid creation out of interaction between colonial rulers and locals who claimed to be or were treated as chiefs, spokespersons, or representatives of their people. ${ }^{123}$ Thus adopting a global perspective may require adjustment in respect of scale, levels of ordering, orientation to the state, and the nature of the subject matters that are said to be examples of "pluralism."

\section{A. "Global Legal Pluralism"}

The term "global legal pluralism" has gained currency in recent years. It has been used by prominent scholars of legal pluralism, including Francis Snyder, Paul Berman, Ralf Michaels, and Sally Merry. ${ }^{124}$ As a concept it is not very promising. We have already seen that each of its constituent elements is problematic: "g-words" such as "global" are repeatedly overused and abused; ${ }^{125}$ there is perpetual debate about the criteria of identification of "the legal"; the ism in pluralism is loosely used to refer to a phenomenon, the study of that phenomenon, or a perspective or lens or school. In addition there lurks the persistent question: plurality of what exactly? The waters are further muddied when "global legal pluralism" is said to be "post-modern.", 126

In a given context, it may be relatively easy to reduce these ambiguities by stipulation. For example, in the context of asking: "what are

123. Barzilai, supra note 1. Cf. Benton's criticism of lingering adherence to structuralism. Benton, supra note 103.

124. E.g., MichaELS, supra note 36; Berman, supra note 49; Merry, supra note 36.

125. TWINING, supra note 10, at 14-16.

126. Gunther Teubner, The Two Faces of Janus: Rethinking Legal Pluralism, 13 CARDozo L. ReV. 1443, 1443-44 (1992). Legal pluralism is sometimes linked with some version of post-modernism or epistemological relativism. Gunther Teubner has aptly suggested that legal pluralism fits the postmodern mood: "Postmodern jurists love legal pluralism. . . . The crucial question of how to reconstruct the postmodern architecture, the connections between the social and legal fields finds a highly vague answer: interpenetrating, intertwined, integral, superposed, mutually constitutive, dialectical . . . . we are left with ambiguity and confusion. After all, this is the very charm of postmodernism." Id. Postmodernism is a broad church, but most of the classical writers about legal pluralism would be surprised to be labelled as "post-modernists." Insofar as the label has associations with epistemological scepticism or relativism, it is quite inappropriate. One can accept the idea of legal pluralism as a social fact without being committed to any form of relativism or non-cognitivism. On the distinction between imaginative post-modernism, and irrationalist or skeptical post-modernism, compare CALVINO, supra note 6 with Richard RoRTy, OBJeCtivity, RElativiSM, AND TRUTH: PHILOSOPHICAL PAPERS (1991) and TWINING, GLT, supra note 3, at 194-241. 
the implications of adopting a global perspective on legal pluralism as a subject of study?", I have argued that it is appropriate to adopt a broad, but not overinclusive conception of law; that g-talk often refers to sub-global phenomena and patterns that are particularly significant for law (former empires, diasporas, legal traditions, etc.); that adopting a global perspective and thinking in terms of maps or total pictures or overviews and geographical levels can capture some of the complexities rather than leading to crude simplifications and over-generalization; and that one answer to the question "plurality of what?" is that the concept of legal pluralism can be applied to institutionalized legal orders or discrete bodies of law that coexist in the same time space context.

Even with this narrowly circumscribed interpretation of "global legal pluralism" there are ambiguities about the term. It could refer to pluralism of genuinely global law: ${ }^{127}$ for example, the coexistence and relations between public international law and the international regime of human rights (if the two are separable). That seems rather narrow. Or it could refer to the coexistence and relations between one genuinely global legal order (e.g., public international law) and one or more other legal orders (e.g., European Community law or French law). Or it could refer to the coexistence and relations between any two or more supra-national or transnational legal orders.

These terminological uncertainties can be viewed as symptomatic of a discipline trying to face up to a new and rapidly changing scene. Some of these ambiguities and vaguenesses can be reduced in specific contexts and some leeway should be accorded to pioneers trying to sketch the parameters of an emerging field. However, the many extensions and applications of the idea of legal pluralism to new phenomena and situations are so many and varied that it is difficult to construct a coherent answer to

127. I have studiously avoided using the term "global law" in this paper. Unfortunately it is becoming increasingly popular. It is variously used to refer to laws or legal orders or institutionalized legal regimes (a) that are genuinely world wide (e.g., the United Nations Convention Against Torture or some aspects of public international law); or (b) that aspire to be world wide (e.g., the International Criminal Court); or (c) that are have a broad, but indeterminate, geographical reach (e.g., lex mercatoria, lex constructionis), see, e.g., Charles Molineux, Moving Toward a Construction Lex Mercatoria: A Lex Constuctionis 20 J. INT'L ARB. 55 (1997); or (d) that are merely international, supranational, or transnational (i.e., any legal phenomenon that transcends national boundaries). In the context of the study of legal pluralism (a) and (b) seem a bit restrictive; (c) is extraordinarily vague, but (d) may be considered too extensive for some purposes. However, the idea of transnational legal pluralism has the potential to capture the range and diversity of the phenomena that are potential subjects of study. 
the question: what is the relevance of classical studies of legal pluralism to the emerging field of "global legal pluralism?"128

This point can be illustrated by the variety of answers given to the question: plurality of what? As we have seen, in the socio-legal literature "pluralism" applied to law was generally, but not universally, used to refer to two or more coexisting normative or legal orders or bodies of rules. ${ }^{129}$ But in the burgeoning recent literature legal pluralism has sometimes been extended to encompass other referents: in globalization discourse much is made of the diversification of significant actors in international relations and international law (see above); international lawyers, concerned about the fragmentation of their subject, point, inter alia, to the proliferation of supranational courts and tribunals (over 130 at a recent count) ${ }^{130}$ and norm creating agencies (such as the ILO, WTO, non-state regulatory agencies, governing bodies of sports such as IOC and FIFA). ${ }^{131}$ Related to this, scholars sometimes refer to "pluralism" of putative, emergent, even fantastical, supranational branches of law: global administrative law, internet law, lex mercatoria, lex sportiva, lex constructionis, ius humanitatis, lex pacificatoria. ${ }^{132}$ Inspired by "the new governance" there is talk of constitutional pluralism and plurinational democracy. ${ }^{133}$ And so on. If "legal pluralism" merely means more than one legal phenomenon without limit on the kinds of phenomenon referred to, it is doubtful whether it is a useful concept and whether the heritage of mainstream socio-legal literature on legal pluralism up to 1990 is very helpful in interpreting these very varied topics.

128. Ralf Michaels has commented, "I would actually phrase the question differently: what can legal pluralism learn from globalization (where I understand globalization as a kind of discourse), and what can globalization learn from legal pluralism? The emerging field (if any) would then consist of these interactions, but it would not be a sub-field of either: globalization without some kind of legal pluralism is inadequate, pluralism without any kind of global impact is rare." E-mail from Ralf Michaels, Professor of Law, Duke University, to William Twining, Professor of Law, University College London (Jan. 2010) (on file with author). I want to restrict "global" to genuinely world wide, so as to emphasise the importance of sub-global patterns especially for law; Michaels uses the term to refer to any interconnectedness that has wide ramifications. This is mainly a semantic difference, for we are both skeptical about the continuities between the mainstream legal pluralism literature and "global legal pluralism."

129. See supra discussion accompanying notes 13-22.

130. See The Project on International Courts and Tribunals, The International JUDICIARY IN CONTEXT 1 (2004), http://www.pict-pcti.org/publications/synoptic_chart/synop_c4.pdf.

131. Berman, supra note 45, at 521-23.

132. See, e.g., Christine Bell, On The Law Of Peace: Peace Agreements And The LeX PACIFICATORIA (2008); Molineux, supra note 127, at 55.

133. The Paradox Of Constituionalism: Constituent Power And Constitutional Form (Martin Loughlin \& Neil Walker eds., 2007); Neil Walker, Out of Place and Out of Time: Law's Fading Co-Ordinates, 14 EDINBURGH L. REV. 13 (2010). 
This should not be taken as a counsel of despair. Most responses to the challenges of "globalization" are taking place in relatively specific contexts without undue concern for some of these abstract conceptual issues. Some excellent work is being produced. ${ }^{134}$ At a more "macro" level this paper suggests that one should be wary of "g-words" and rash universalist generalizations, but adopting a global perspective can be useful in constructing broad brush overviews (or "maps," if one does not take geographical metaphors too literally); that it is important to differentiate different levels of relations and of ordering; that genuinely global phenomena, issues, and solutions represent a quite narrow category, but that there are some sub-global transnational patterns that are helpful in constructing such maps; that such concepts as legal tradition, institutionalized normative orders, and sets or bodies of norms are useful in indentifying legal phenomena; that workable distinctions between legal and non-legal social institutions and norms can be constructed in specific contexts; and that in adopting a global perspective one should be aware of widespread inherited assumptions in our own legal tradition(s) that are challenged by "globalization." Most important, this mildly positivistic demographic realism in mapping legal phenomena in the world is only useful up to a point-in sketching a broad context for more particular studies - and the broad concepts it involves should not be expected to do too much work at lower levels of abstraction or for more specific inquiries. For this kind of purpose it is helpful to treat legal pluralism as a species of normative pluralism, to be sensitive to problems of individuation (of norms, normative orders, and legal traditions), and to be specific about plurality of what.

Adopting a global perspective further decenters the state, without implying that states are unimportant in respect of de facto power, claims to authority, and perhaps offering the best hope for democracy, protection of rights, and good governance. Such a perspective raises questions about the significance of a sharp distinction between state (or weak) legal pluralism and non-state (or strong) legal pluralism: for one thing, state (municipal) law mainly operates at only one level of the multiple layers of normative and legal ordering.

134. See, e.g., Berman, supra note 45; Michaels, supra note 36; PARADOX OF CONSTITUTIONALISM, supra note 133. 


\section{CONCLUSION}

(1) Legal pluralism scholarship has produced a rich heritage of particular studies and some unsatisfactory theorizing. Recently, the idea of "global legal pluralism" has further muddied the waters.

(2) We all encounter normative pluralism every day of our lives. We treat it as a social fact and rarely speculate about it. If one treats legal pluralism as a species of normative pluralism, this helps to de-mystify legal pluralism by de-centering the state, providing links to a rich body of literature, and showing that some of the puzzlements surrounding pluralism can usefully be viewed as much broader issues of general normative and legal theory.

(3) Conceptual elucidation of key terms can draw on several disciplines regarding, for example, pluralism, individuation, normative pluralism, state centrism, normativity, coexistence, religion, custom, and recognition. Similarly, puzzles about conceptualizing law and legal positivism are not puzzles about legal pluralism as such.

(4) The mainstream literature on legal pluralism has quite diverse intellectual roots. It is difficult to generalize about, except that the very idea of legal pluralism typically presupposes a conception of non-state law. However, one can construct an ideal type of "social fact [legal] pluralism" to which most anthropological and socio-legal studies up to the mid-1990s approximated. This was empirically oriented and focused mainly on institutionalized normative orders in opposition to state centrism. It tended to be framed quite narrowly, excluding state legal pluralism and other matters internal to a state legal system, such as competing schools of interpretation, polycentricity, and even conflicts of laws. It was generally not much concerned with normative questions and practical issues.

(5) Discourse on globalization led, perhaps inevitably, to talk of "global legal pluralism," a concept which is radically ambiguous in relation to all three component terms. The question arises: what might be the relationship between social fact legal pluralism and this new set of concerns?

(6) "Globalization" is challenging settled assumptions of Western traditions of academic law. Legal pluralism studies, especially social fact pluralism, are perhaps less wedded to some of these assumptions: they oppose state centrism, they accept some idea of "non-state law," they take religion seriously, and they have more of an empirical orientation than doctrinal legal studies.

(7) Several factors, however, challenge any strong claims to continuity. 
(a) Social fact pluralism grew out of a tradition that largely focused on face-to-face local communities at the sub-national level. The range of subject matters and actors was a far cry from questions about international terrorism, the fragmentation of international law, regulation of transnational finance and commerce, regional integration, and trafficking of drugs or humans.

(b) Social fact legal pluralism was mainly concerned with plurality of coexisting institutionalized normative orders. "Global legal pluralism" gives a much more varied answer to the question: plurality of what? In this context, the term "pluralism" has been applied indiscriminately to almost any kind of complexity or diversity. Moving the central legacy of insights onto a world stage involves significant changes in scale, subject matters, and central concerns. The idea of "pluralism" applied to actors, courts, schools of thought, centers of power, sources of norms, levels of relations and ordering, cultures, or even the proliferation of human rights means little more than diversity. Post-modern enthusiasm for fragmentation, diversification and indeterminacy threatens to reduce the usefulness of "pluralism" as an analytic concept. We are threatened with a not very illuminating plurality of pluralisms. ${ }^{135}$ It is not clear how far the heritage of social fact pluralism studies can be very helpful in interpreting these very varied topics.

(c) Insofar as social fact pluralism studies have been largely descriptive rather than normative, one should not expect much practical normative guidance about such issues as institutional design, state policy, or rights-based approaches to development.

(d) As borders become more porous and state sovereignty is challenged, are sharp distinctions between the internal and external aspects of state legal systems still tenable? From a global perspective, state (weak) legal pluralism, conflicts of laws, and the politics of recognition transcend distinctions between state and non-state law and are all relevant to making sense of pluralism.

(8) However, the social fact literature, by emphasizing the fact of the coexistence of significant institutionalized bodies of social norms and practices and the importance of "local knowledge," is helpful in at least four ways:

(a) It draws attention to the existence of normative orders that are generally ignored, overlooked, arcane, or even invisible;

(b) In the context of diffusion/transplantation it provides a reminder that norms based on foreign models are rarely introduced into a

135. See supra text accompanying notes 5-7. 
vacuum (the blank slate fallacy), but will inevitably have to interact with preexisting local arrangements, which will often include significant institutionalized normative orders;

(c) It focuses attention on interlegality - the many different and complex ways in which multiple legal and normative orders can relate to each other and interact; and

(d) It focuses attention on issues of state policy concerning relations between the state and different communities and belief systems in a multicultural society. But insofar as one adopts a social fact view of normative pluralism, this will on its own provide little direct guidance on normative questions about legitimacy, justification, toleration, and recognition of non-state legal orders. 